\title{
Greenhouse Effect and Sea Level Rise: The Cost of Holding Back the Sea
}

\section{JAMES G.TITUS}

Office of Policy Analysis

U.S. Environmental Protection Agency

Washington, DC 20460

\section{RICHARD A. PARK}

School of Public and Environmental Affairs

Indiana University

Bloomington, IN 47405

\section{STEPHEN P. LEATHERMAN}

Department of Geography

University of Maryland

College Park, MD 20742

\section{J. RICHARD WEGGEL}

Department of Civil and Architectural Engineering

Drexel University

Philadelphia, PA 19104

\section{MICHAEL S. GREENE}

The Bruce Company

Washington, DC 20024

\section{PAUL W. MAUSEL}

Department of Geography and Geology

Indiana State University

Terre Haute, IN 47809

\section{SCOTT BROWN}

JCA Associates

Mt. Laurel, NJ 08054

\section{GARY GAUNT}

Science Applications International Corporation

Mclean, VA 22102

\section{MANJIT TREHAN}

Indiana University and Purdue University at Indianapolis Indianapolis, IN 46202

\section{GARY YOHE}

Department of Economics

Wesleyan University

Middletown, CT 06457 


\begin{abstract}
Previous studies suggest that the expected global warming from the greenhouse effect could raise sea level 50 to 200 centimeters ( 2 to 7 feet) in the next century. This article presents the first nationwide assessment of the primary impacts of such a rise on the United States: (1) the cost of protecting ocean resort communities by pumping sand onto beaches and gradually raising barrier islands in place; (2) the cost of protecting developed areas along sheltered waters through the use of levees (dikes) and bulkheads; and (3) the loss of coastal wetlands and undeveloped lowlands. The total cost for a one-meter rise would be $\$ 270-475$ billion, ignoring future development.

We estimate that if no measures are taken to hold back the sea, a one meter rise in sea level would inundate 14,000 square miles, with wet and dry land each accounting for about half the loss. The 1500 square kilometers (600-700 square miles) of densely developed coastal lowlands could be protected for approximately one to two thousand dollars per year for a typical coastal lot. Given high coastal property values, holding back the sea would probably be cost-effective.

The environmental consequences of doing so, however, may not be acceptable. Although the most common engineering solution for protecting the ocean coast $\bullet$ pumping sand $\bullet$ would allow us to keep our beaches, levees and bulkheads along sheltered waters would gradually eliminate most of the nation's wetland shorelines. To ensure the long-term survival of coastal wetlands, federal and state environmental agencies should begin to lay the groundwork for a gradual abandonment of coastal lowlands as sea level rises.
\end{abstract}

Keywords: sea level rise, erosion, economics, wetlands, greenhouse effect, climatic change.

\title{
Introduction
}

At the turn of the century, scientific opinion regarding the practical implications of the greenhouse effect was sharply divided. Since the 1860s, people had known that by absorbing outgoing infrared radiation, atmospheric $\mathrm{CO}_{2}$ keeps the earth warmer than it would otherwise be (Tyndall, 1863). Svante Arrhenius (1896), who coined the term "greenhouse effect," pointed out that the combustion of fossil fuels might increase the level of $\mathrm{CO}_{2}$ in the atmosphere, and thereby warm the earth several degrees. Because the 19th century had experienced a cooling trend, however, others speculated that the oceans and plant life might gradually reduce $\mathrm{CO}_{2}$ levels and cause an ice age (Barrel et al., 1919).

Throughout the first half of the 20th century, scientists generally recognized the significance of the greenhouse effect, but most thought that humanity was unlikely to substantially alter its impact on climate. The oceans contain 50 times as much $\mathrm{CO} 2$ as the atmosphere, and physical laws governing the relationship between the concentrations of $\mathrm{CO} 2$ in the oceans and in the atmosphere seemed to suggest that this ratio would remain fixed, implying that only 2 percent of the $\mathrm{CO} 2$ released by human activities would remain in the atmosphere. This complacency, however, was shattered in 1957 when Revelle and Seuss (1957) demonstrated that the oceans could not absorb $\mathrm{CO} 2$ as rapidly as humanity was releasing it: "Human beings are now carrying out a large-scale geophysical experiment." Only then were monitoring stations set up to measure worldwide trends in atmospheric concentrations. By the mid 1960s, it was clear that Revelle and Seuss had been correct (President's Science Advisory Committee, 1965).

In the last decade, climatologists have reached a consensus that a doubling of $\mathrm{CO}_{2}$ would warm the earth 1.5-4.5 $\mathrm{C}\left(3-8^{\circ} \mathrm{F}\right)$, which could leave our planet warmer than it has ever been during the last two million years (National Academy of Sciences, 1979). Moreover, humanity is increasing the concentrations of other gases whose combined greenhouse effect could be as great as that due to $\mathrm{CO}_{2}$ alone, including methane, chlorofluorocarbons, nitrous oxide, and sulfur dioxide (Ramanathan et al., 1985). Even with the recent agreement to curtail the use of CFCs, global temperatures could rise as much as $5^{\circ} \mathrm{C}\left(9^{\circ} \mathrm{F}\right)$ in the next century 
(Smith and Tirpak, 1988). Global warming would alter precipitation patterns, change the frequency of droughts and severe storms, and raise the level of the oceans.

This article presents the first attempt to quantify the nationwide impacts of an accelerated rise in sea level. The study was undertaken in response to a request from the U.S. Congress to the Environmental Protection Agency, and had to be completed in twelve months with a budget of $\$ 300,000$. With these constraints, we were only able to focus on the loss of dry and wet land and the cost of holding back the sea.

Because our focus was on aspects that can be most readily estimated on a nationwide basis, we have disregarded impacts that importance is limited to a few areas--in particular the threat to coastal water supplies from saltwater intrusion and the unique situation in Louisiana. We hope that this study will motivate others to improve on the methods presented here and to start quantifying other impacts of global warming.

\section{Causes and Effects of Sea Level Rise}

\section{Climate and Sea Level}

The level of the oceans has always fluctuated with changes in global temperatures. During ice ages when global temperatures were $5^{\circ} \mathrm{C}\left(9^{\circ} \mathrm{F}\right)$ lower than today, much of the ocean's water was tied up in glaciers and sea level was often over one hundred meters (three hundred feet) lower than today (Donn et al., 1962; Kennett, 1982; Oldale, 1985). On the other hand, during the last interglacial period (100,000 years ago) when temperatures were about $1^{\circ} \mathrm{C}\left(2^{\circ} \mathrm{F}\right)$ warmer, sea level was approximately 6 meters (20 feet) higher than today (Mercer, 1970).

When discussing shorter periods of time, one must distinguish worldwide (eustatic) sea level rise from relative sea level rise, which includes land subsidence. Although climate affects worldwide sea level, the rate of sea level rise relative to a particular coast has more practical importance and is all that current monitoring stations can measure. Because some coastal areas are sinking while others are rising, relative sea level rise in the United States varies from more than one meter (three feet) per century in Louisiana and parts of California and Texas, to thirty centimeters (one foot) per century along most of the Atlantic and Gulf Coasts, to a slight drop in much of the Pacific Northwest as shown in Figure 1.

Global sea level trends have generally been estimated by combining the trends at tidal stations around the world. These records suggest that during the last Century, worldwide sea level has risen 10 to $25 \mathrm{~cm}$ (4 to 10 in) (Barnett, 1984; Peltier and Tushingham, 1989), much of which has been attributed to the global warming of the last century (Gornitz et al., 1982; Meier, 1984).

The projected global warming could raise worldwide sea level by expanding ocean water, melting mountain glaciers, and causing the ice sheets of Greenland and Antarctica to melt or slide into the oceans. A report by the Department of Energy estimated that over a period of two to five hundred years, the West Antarctic Ice Sheet could disintegrate, raising sea level 6 meters (20 feet) (Bentley, 1983; Hughes, 1983). Studies after 1983, however, have focused on the next century. Figure 2 illustrates recent estimates of sea level rise, which generally fall into the range of 50 to $200 \mathrm{~cm}$ ( 2 to 7 feet) by 2100; Studies since 1990, however, generally suggest that the $50-200 \mathrm{~cm}$ rise is more likely to take $150-200$ years. This assessment uses rises of 50,100 , and $200 \mathrm{~cm}$.

Although the most recent reports have been at the lower end of the range, recent press accounts have exaggerated the extent to which those reports should be viewed as downward revisions. Meier's (1990) recent paper (entitled Reduced Rise in Sea Level), led major newspapers to report that sea level projections are being lowered. However, as Figure 2 shows, the main reason the projections were lower was that Meier changed his target year from 2100 to 2050 .

The Intergovernmental Panel on Climate Change (1990) released projections that were lower than most previous studies, based on the assumption that Antarctica will accumulate more ice in response to global warming, an assumption that has not met universal acceptance from glaciologists. Clearly, the models are unable to adequately estimate how much sea level will rise; and the experts disagree. Under these 
circumstances, revisions of sea level projections are just as likely to result from changes in who chairs the panel that forecasts sea level rise as from any new information [but sea level rise projections have been reduced substantially since this report was first written. See Chapter 8 of "The Probability of Sea Level Rise" by EPA for a discussion of the downward revisions.]

\section{U.S. Sea Level Trends: 1900-97}

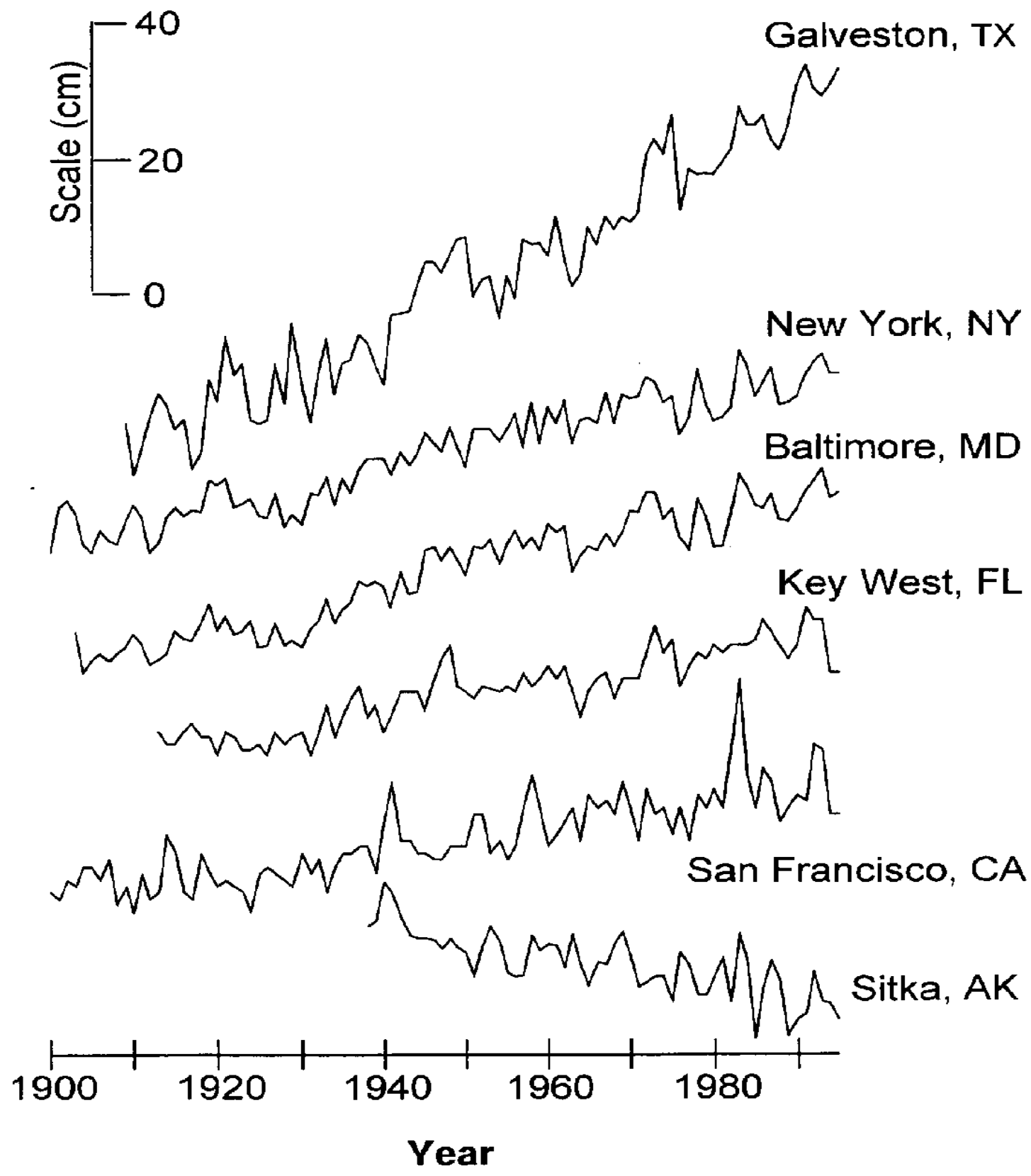

Figure 1. Time series graph of sea level trends for New York, Charleston, Miami, Grand Isle, Galveston, San Francisco, and Sitka. Source: Lyle et al. (1988). 


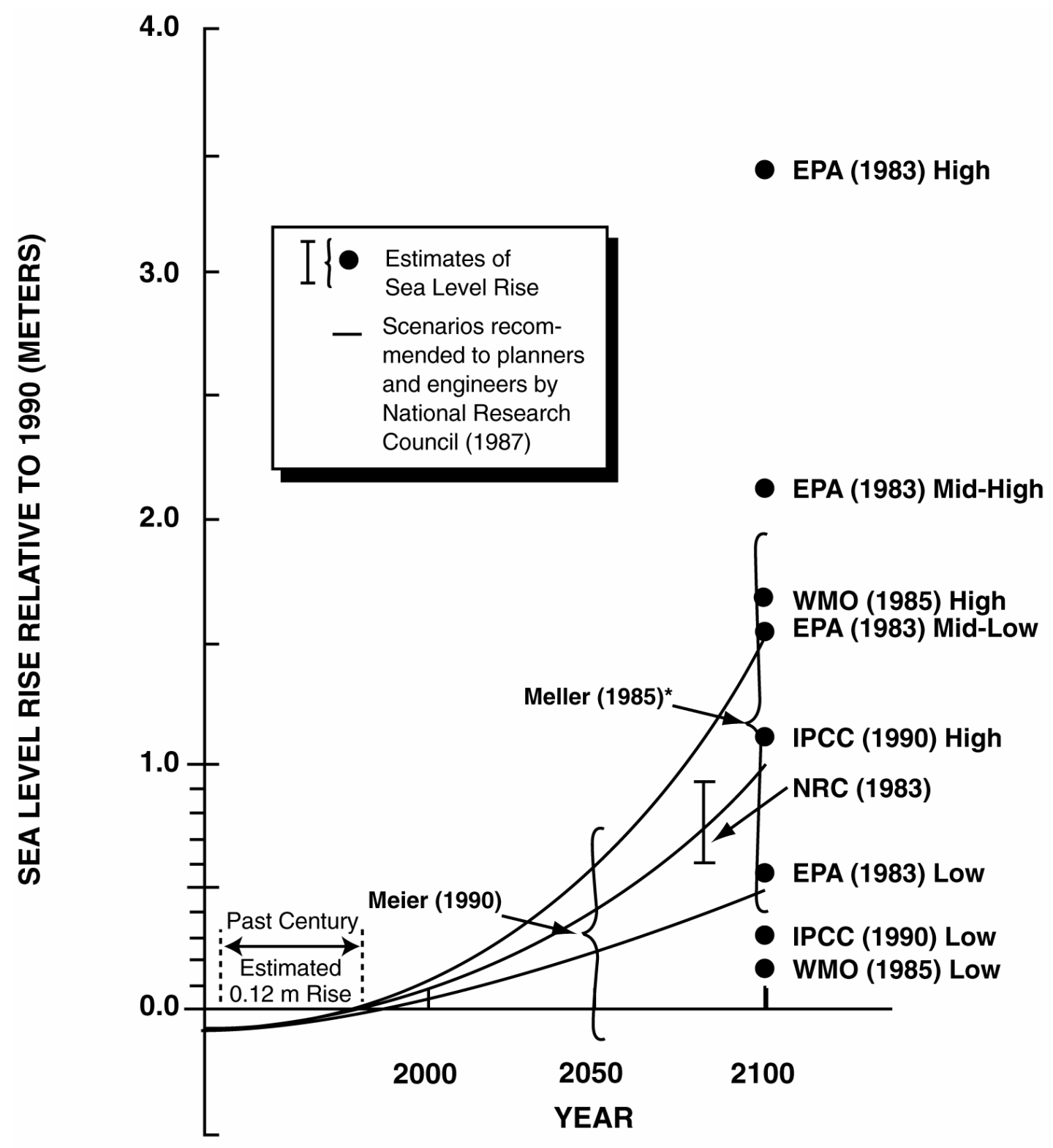

Figure 2. Estimates of future sea level rise. Sources: U.S. EPA (1983); IPCC (1990); Meier (1990); Meier et al. (1985); NRC ( 1983); NRC (1987); WMO (1985).

The greenhouse effect would not necessarily raise sea level by the same amount everywhere. Removal of water from the world's ice sheets would move the earth's center of gravity away from Greenland and Antarctica; the oceans' water would thus be redistributed toward the new center of gravity. Along the coast of the United States, this effect would generally increase sea level rise by less than 10 percent; sea level could actually drop, however, at Cape Horn and along the coast of Iceland (Clark and Lingle, 1977). Climate change could also influences local sea level by changing winds, atmospheric pressure, and ocean currents, but no one has estimated these impacts. 


\section{Effects of Sea Level Rise}

A rise in sea level would inundate wetlands and lowlands, accelerate coastal erosion, exacerbate coastal flooding, threaten coastal structures, raise water tables, and increase the salinity of rivers, bays, and aquifers (Barth and Titus, 1984). Most of the wetlands and lowlands of the United States are found along the Gulf Coast and the Atlantic coast south of the central part of New Jersey, although there is also a large low area around San Francisco Bay. Similarly, the areas vulnerable to erosion and flooding are also predominantly in the southeast, while potential salinity problems are spread more evenly throughout the coast. We briefly describe the impacts that would result if nothing were done to address sea level rise, and then discuss the responses that have been investigated in the last several years.

Shoreline Retreat. Coastal marshes and swamps are generally found between the highest tide of the year and mean sea level ${ }^{1}$. Because they collect sediment and produce peat upon which they can build, most wetlands have been able to keep pace with the past rate of sea level rise (e.g. Kaye and Barghoom). Thus, as Figure 3a$3 \mathrm{c}$ illustrate, the area of wetlands today is generally far greater than the area that would be available for new wetlands if sea level rose too rapidly (Titus, 1986; Titus, 1988) ${ }^{2}$. The potential loss would be the greatest in Louisiana (U.S. Environmental Protection Agency and Louisiana Geological Survey, 1987). Moreover, in many areas people have built bulkheads just above the marsh; if sea level rose, the wetlands would be squeezed between the estuary and the bulkhead (Figure 3). Such a loss would reduce available habitat for birds and juvenile fish, and would reduce the production of organic materials on which estuarine fish rely.

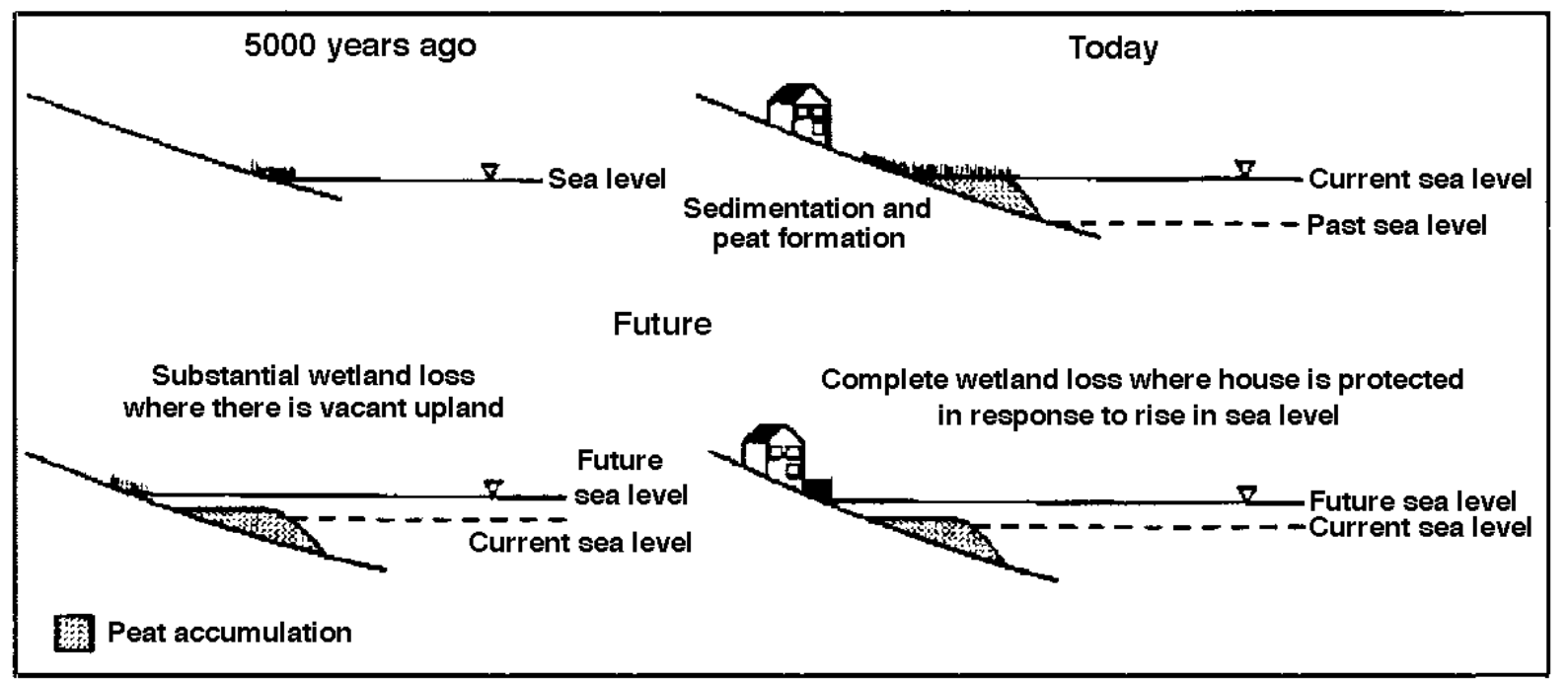

Figure 3. Impact of Sea Level Rise on a Marsh. Coastal wetlands have kept pace with the slow rate of sea level rise that has characterized the last several thousand years. Thus, the area of wetlands increased as new lands were inundated. If in the future sea level rises faster than the ability of the wetlands to keep pace, the wetland area will decline. Construction of bulkheads, dikes, and the artificial elevation of nearby developed lands would prevent new wetlands from forming inland, resulting in a total less in some areas. Source: Titus (1986).

The dry land within two meters (seven feet) of high tide include forests, farms, low parts of some port cities, communities that sank after they were built and are now protected with levees, and the bay sides of barrier islands. The low forests and farms are generally in the mid-Atlantic and southeast, and would provide potential areas for new wetland formation. Major port cities with low areas include Boston, New York, Charleston, Miami, and New Orleans; the latter averages about two meters below sea level, and parts of Texas City, San Jose, and Long Beach California are about one meter below sea level. 
Some of the most important vulnerable areas are the recreational barrier islands and spits of the Atlantic and Gulf Coasts. Coastal barriers are generally long narrow islands and spits (peninsulas) with the ocean on one side and a bay on the other. Typically, the oceanfront block of an island ranges from two to four meters above high tide, while the bay side is less than a meter above high water. Thus, even a one-meter rise in sea level would threaten much of this valuable land with inundation.

(a) Initial Condition

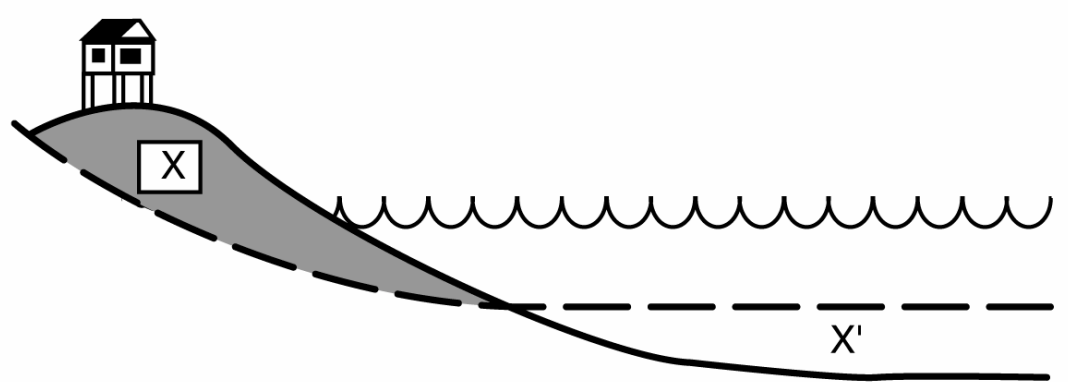

(b) Innundation

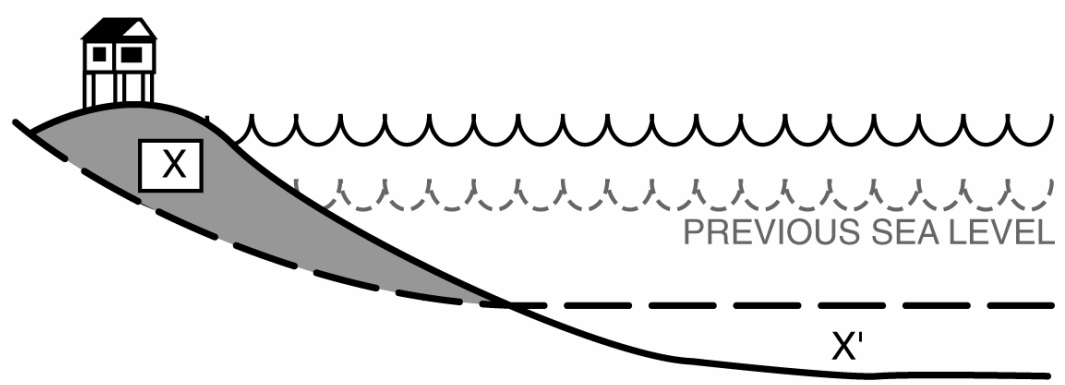

(c) Subsequent Erosion

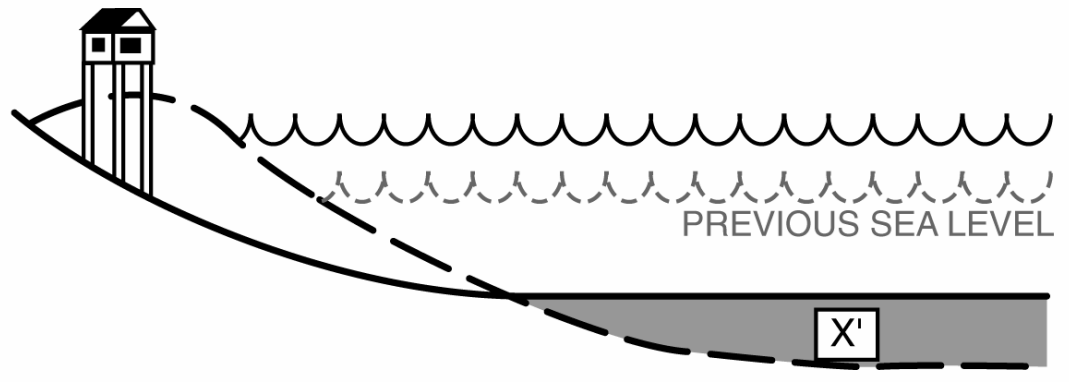

Figure 4. The Bruun Rule. A rise in sea level immediately results in shoreline retreat due to inundation, as shown in $a$ and $b$. (a) Initial condition; (b) immediate inundation when sea level rises; (c) subsequent erosion due to sea level rise. However, a 3-foot rise in sea level implies that the offshore bottom must also rise 3 feet. The sand required to raise the bottom $\left(\mathrm{X}^{\prime}\right)$ can be supplied by beach nourishment. Otherwise, waves will erode the necessary sand $(\mathrm{X})$ from upper part of the beach as shown in $(c)$.

Source: Titus (1986)

Erosion, moreover, threatens the high parts of these islands, and is generally viewed as a more immediate problem than the inundation of their bay sides. As Figure 4 shows, a shape of a beach profile is determined by the pattern of waves striking the shore; generally, the visible part of the beach is much steeper than the 
underwater portion, which comprises most of the active "surf zone." While inundation alone is determined by the slope of the land just above the water, Bruun (1962) showed that the total shoreline retreat from a rise in sea level depends on the average slope of the entire beach profile.

Previous studies suggest that a one meter rise in sea level would generally cause beaches to erode 50-100 meters from the Northeast to Maryland; 200 meters along the Carolinas; 100-1000 meters along the Florida coast; and 200-400 meters along the California coast (Everts, 1985; Kyper and Sorensen, 1985; Kana et al, 1984; Bruun, 1962; Wilcoxen, 1986). Because most U.S. recreational beaches are less than 30 meters (100 feet) wide at high tide, even a thirty-centimeter (one foot) rise in sea level would require a response.

Flooding. Coastal areas would become more vulnerable to flooding for four reasons: (1) A higher sea level provides a higher base for storm surges to build upon; a one meter rise in sea level would thus enable a 15-year storm $^{3}$ to flood many areas that today are only flooded by a 100-year storm (Kana et al., 1984). (2) Beach erosion would leave particular properties more vulnerable to storm waves. (3) Higher water levels would increase flooding due to rainstorms by reducing coastal drainage (Titus et al., 1987). (4) Finally, a rise in sea level would raise water tables.

Many coastal areas are protected with levees and seawalls, and would thus not necessarily experience inundation, erosion, or flooding. However, these structures have been designed for current sea level. Higher water levels would threaten the integrity of these coastal structures because (1) higher flood levels might overtop them, and (2) erosion could undermine them from below (National Research Council, 1987). In areas like New Orleans that are drained artificially, the increased need for pumping could exceed current capacities (Titus et al., 1987).

Saltwater Intrusion. Finally, a rise in sea level would enable saltwater to penetrate farther inland and upstream in rivers, bays, wetlands, and aquifers, which would be harmful to some aquatic plants and animals, and would threaten human uses of water. Increased salinity has already been cited as a contributing factor to reduced oyster harvests in the Delaware (Gunter, 1974) and Chesapeake Bays, and for converting cypress swamps in Louisiana to open lakes (U.S. Environmental Protection Agency and Louisiana Geological Society, 1987). Moreover, New York, Philadelphia, and much of California's Central Valley get their water from areas that are just upstream from where the water is salty during droughts. Farmers in central New Jersey as well as the city of Camden rely on the Potomac-Raritan-Magothy aquifer, which could become salty if sea level rises (Hull and Titus, 1986). The South Florida Water Management District already spends millions of dollars per year to prevent Miami's Biscayne aquifer from becoming salty (Miller et al., 1989).

\section{Responses}

Inundation, Erosion, and Flooding. Possible responses fall broadly into three categories: erecting walls to hold back the sea; allowing the sea to advance and adapting to it; and raising the land. The slow rise in sea level over the last thousand years and the areas where land has been sinking more rapidly offer numerous historical examples of all these responses. For over five centuries, the Dutch have used dikes and windmills to prevent inundation from the North Sea. By contrast, many cities have been rebuilt landward as structures and land were lost to erosion; the town of Dunwich, England has had to rebuild its church seven times in the last seven centuries. More recently, rapidly subsiding communities such as Galveston, Texas, have used fill to raise land elevations; The U.S. Army Corps of Engineers and coastal states regularly pump sand from offshore to counteract beach erosion. Venice is a hybrid of all three responses, allowing the sea to advance into the canals, while raising some low lands and erecting storm protection barriers.

Most assessments in the United States have concluded that low-lying coastal cities would be protected with bulkheads, levees, and pumping systems, while in sparsely developed areas shorelines would retreat naturally (National Research Council, 1987). This conclusion has generally been based on the commonly accepted assumption that the cost of these structures would be far less than the value of urban areas being protected but greater than the value of undeveloped land.

Studies on the possible responses of barrier islands (Titus, 1985; Howard et al., 1985) and moderately developed mainland communities (Kana et al., 1986; Titus, 1988) suggest that environmental and aesthetic 
factors would be as important as economics. Figure 5 illustrates four possible responses by which barrier islands could respond to sea level rise: no protection, engineering a landward retreat, raising the island in place, and building a levee. A case study of Long Beach Island, New Jersey, concluded that all three protection options are far less costly than the value of the land that would be threatened. Although levees and retreat are somewhat less expensive than raising islands, the latter option would probably be preferred because (1) constructing levees and seawalls would result in the loss of beaches and waterfront views; and (2) retreat would not be feasible for islands with high-rises and would only be marginally less expensive for moderately developed islands, while requiring major changes in how people view ownership of coastal property (Titus, 1990).
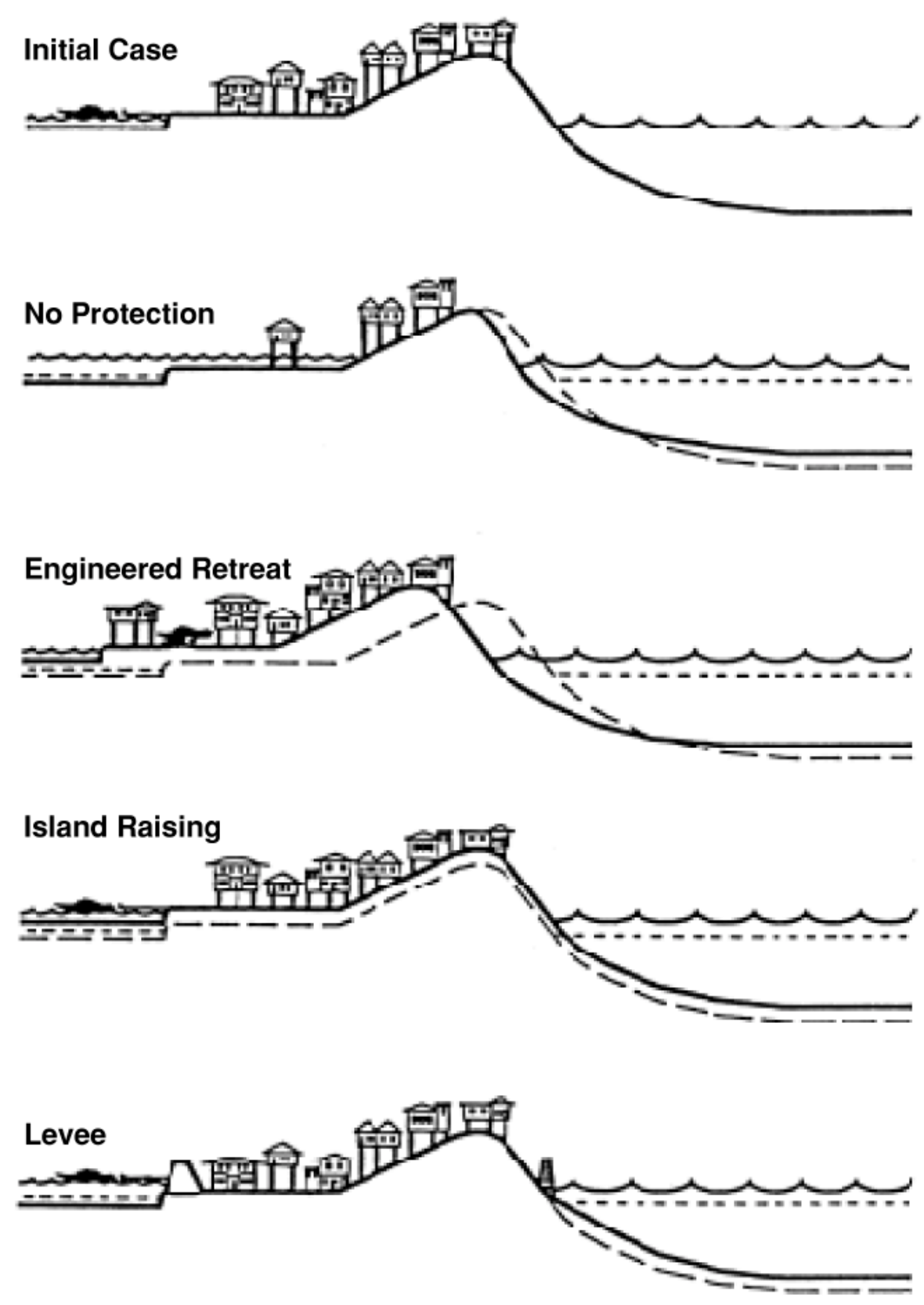

Legend: Original Sea Level; - - - - - - - Original Beach Profile

Figure 5. Responses to sea level rise for developed barrier islands. Source: Titus (1990) 
Responses to erosion are more likely to have adverse environmental impacts along sheltered water than on the open coast. Because the beach generally is a barrier island's most important asset, economics would encourage ocean beach communities to preserve their natural shorelines; and preventing the island from breaking up would also protect the adjacent wetlands. But along most mainland shorelines, economic selfinterest would encourage property owners to erect bulkheads, which would prevent new wetland formation from offsetting the loss of wetlands that were inundated. Figure 6 illustrates possible policy responses for ensuring that development does not block the inland migration of coastal wetlands.

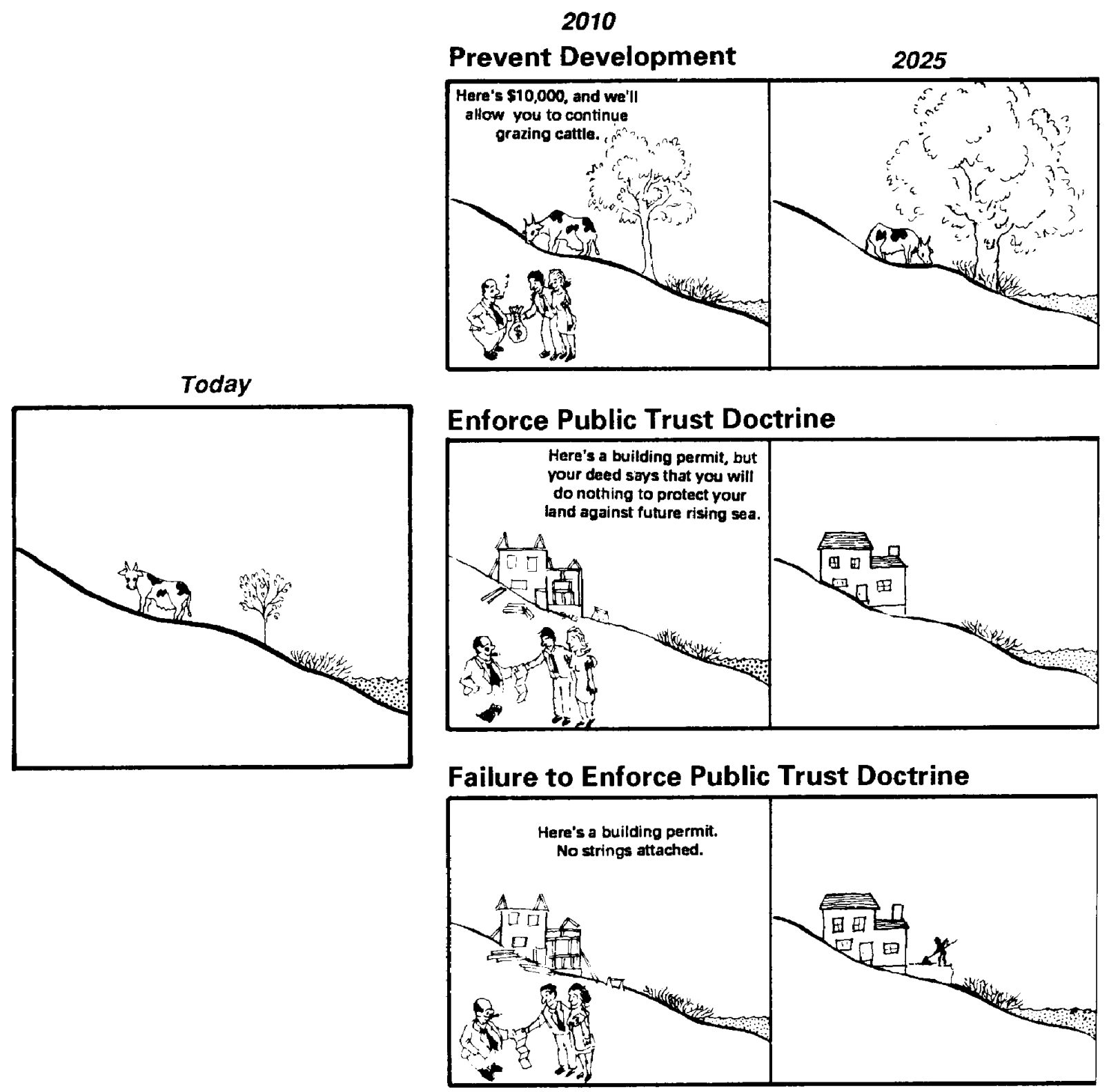

Figure 6a: Options for enabling wetlands to migrate inland. 
Saltwater Intrusion. Most of the measures for counteracting saltwater intrusion due to sea level rise have also been employed to address current problems. The Delaware River Basin Commission, for example, protects Philadelphia's freshwater intake on the river--as well as New Jersey aquifers recharged by the river--from excessive salinity by storing water in reservoirs during the wet season and releasing it during droughts, forcing the saltwater back toward the sea (Hull and Titus, 1986). Other communities have protected coastal aquifers by erecting underground barriers and by maintaining freshwater pressure through the use of impoundments and injection wells (Sorensen et al., 1984).
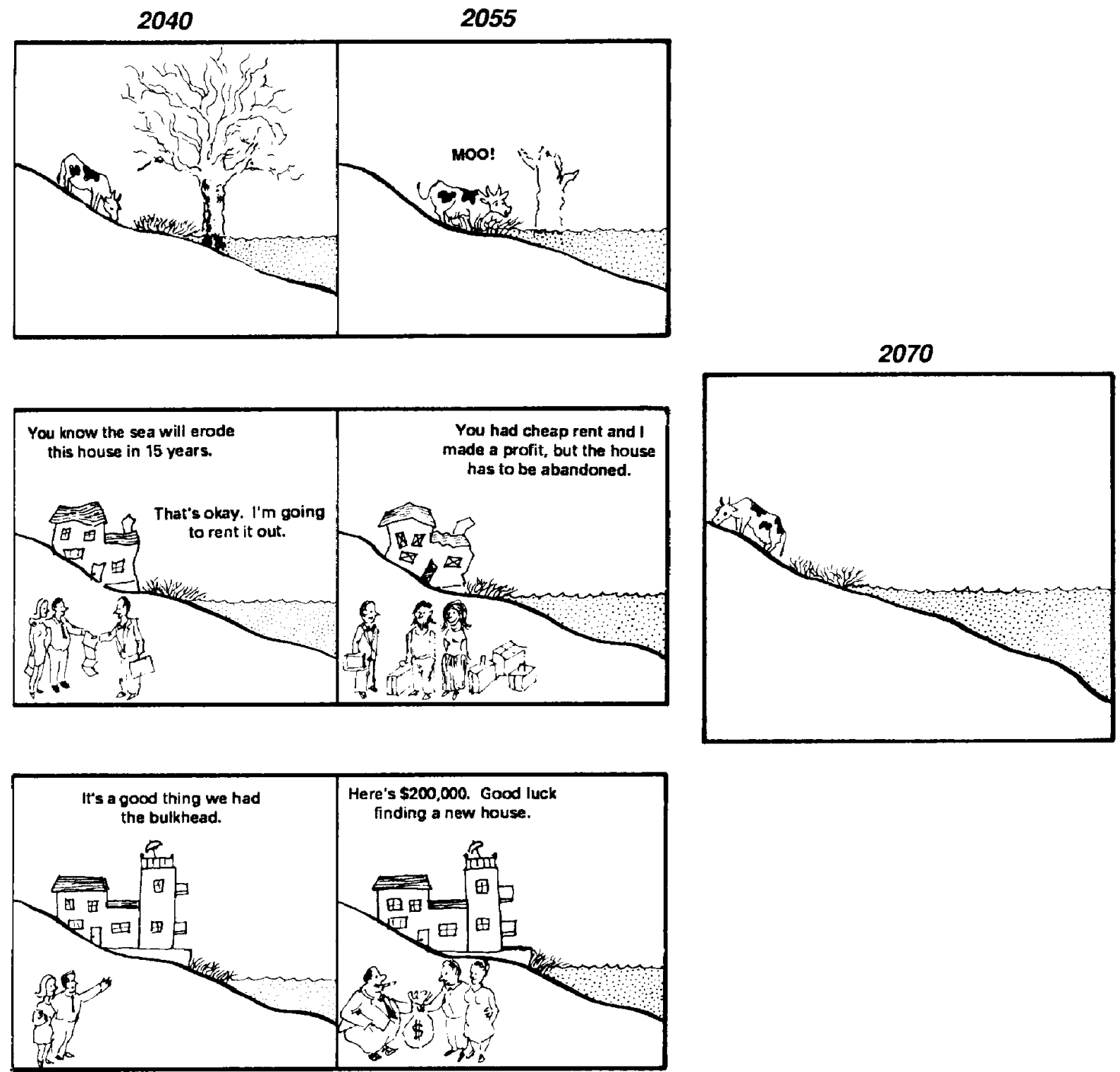

Figure 6b: Options for enabling wetlands to migrate inland. 


\section{Projecting the Nationwide Impacts: Objectives and Strategy}

Ideally, we would like to know the economic and environmental impacts of all the possible scenarios of sea level rise for all possible policy responses for every coastal community in the nation. Every community would then have sufficient information to rationally consider how it should respond. Moreover, we could estimate the nationwide impact by picking the best policy response for each community and adding all the costs. However, because such a comprehensive analysis is not yet possible, our study had the more limited objective of developing nationwide estimates that considered as many factors as possible.

Our first step was to choose which of the impacts to study. We chose shoreline retreat (i.e., erosion and inundation) for several reasons: First, we excluded saltwater intrusion because only two case studies had examined the physical impacts and none had examined the economic impact of rising sea level; the processes are too complicated to meaningfully represent without detailed models; and the unavoidable ${ }^{4}$ economic and environmental impact of increased salinity appeared to be an order of magnitude less than shoreline retreat-and much more sensitive to possible changes in the frequency of droughts than to sea level rise (Hull and Titus, 1986). We would have liked to include flooding, which is closely related to shoreline retreat, but the cost of applying flood models to a large number of sites was prohibitive, and models of the resulting property damage are inaccurate without detailed surveys of the elevations and types of structures.

By contrast, estimating the impacts of (1) natural shoreline retreat and (2) holding back the sea seemed feasible. In the former case, estimating inundation of dry land simply requires one to determine its elevation; wetland loss requires the elevation and an assumption regarding how rapidly the wetlands might accrete; beach erosion can be approximated using topographic maps and the Bruun (1962) rule; and the value of lost land can be estimated using tax maps. The costs of holding back the sea are also fairly straightforward: Wetland loss is estimated the same way as under the natural retreat scenario, except that one must specify which areas are likely to be protected from the sea (and hence, unavailable for creation of new wetlands); the cost of nourishing beaches can be derived using data collected by the Corps of Engineers; and the cost of elevating land, houses, and of erecting shore-protection structures can be estimated by engineers based on experience.

Moreover, the procedures for assessing shoreline retreat tend to implicitly account for flooding caused by storm surges (at least after the first foot of sea level rise). Where development is protected from sea level rise, levees and pumping systems used for preventing inundation would also prevent sea level rise from increasing flood damages; and raising barrier islands and the structures on them by the amount of sea level rise would

leave flood risks constant. ${ }^{5}$ Where development is unprotected, the estimates of lost land and structures would probably account for the costs of increased flooding; although flood plains would move inland, the value of structures standing in the new flood plain would be approximately balanced by the inundated structures that are lost. Nevertheless, for the first foot of sea level rise, examining shoreline retreat probably does not account for flooding: if development is protected, major measures would probably not be taken to counteract the first foot, so the frequency of flooding would increase. If development is not protected, the first foot would increase flooding but not threaten many structures with inundation.

At the outset, it was clear that it would not be possible to estimate both the cost of holding back the sea and the cost of not holding it back with the resources we were allotted. We chose to focus on the former because it currently seems more likely. We would learn little, for example, from estimating the value of buildings on Manhattan Island that would be lost if the sea was not held back; because of its value, we know Manhattan will be protected, and that assuming otherwise in a nationwide study would substantially skew the results. By contrast, assuming that shores would be protected in a lightly developed area more likely to be abandoned would introduce a more modest error.

Accordingly, we divided the assessment into three tasks:

(1) Estimating the areas of dryland and wetlands that would be lost for various scenarios.

(2) Estimating the cost of protecting developed areas along sheltered coasts.

(3) Estimating the cost of protecting developed areas along the open coast. 
Each task used four scenarios of sea level rise: the historic trend of $12 \mathrm{~cm}$ per century, and accelerated rises of 50,100 , and $200 \mathrm{~cm}$ by the year 2100 . In all cases, local subsidence was added to the projections of global sea level rise.

\section{Loss of Coastal Wetlands and Dry Land}

\section{MethodsMethods}

This part of the study was based on a sample of 46 coastal sites selected at regular intervals along the coast, accounting for 10 percent of the contiguous U.S. coastal zone. Because of funding constraints, we had to exclude Alaska, Hawaii, and the U.S. territories.

This task required us to (1) characterize existing elevations and (2) model the impact of sea level rise. We estimated elevations of dry land by interpolating between contours on U.S. Geological Survey topographic maps. For wetlands, however, the procedure was more complicated: First we determined the dominant wetland types (e.g. high marsh, low marsh, mangrove) for 57- by 79-meter "pixels", based on LANDSAT imagery (DeSarthy, 1974). (Because of computer limitations, these pixels had to be aggregated to 500-meter squares.) We then calculated the distribution of wetland elevations based on known tidal ranges, ${ }^{6}$ the relationship between tides and wetland types (Lefor et al., 1987), and the assumption that elevations for particular wetland types are distributed uniformly between their upper and lower bounds.

Given our estimates of current elevations, we estimated loss of wet and dry land for three scenarios of shoreline protection: no protection, (standard) protection of currently developed areas, and (total) protection of all shores. Although estimating the loss of dry land depends solely on current elevations, determining the loss of coastal wetlands requires an assumption regarding vertical accretion. Because no one had assessed the possible impact of global warming and sea level rise on accretion, we assumed that current accretion rates would continue.

An evaluation of the implications of coastal land loss is outside the scope of this report. Nevertheless, the reader interested in understanding the entire economic impact of sea level rise requires at least a rough conversion of the wetland loss estimates into monetary terms. We use high and low assumptions of $\$ 6,000$ and $\$ 30,000$ per acre. The first assumption is based on the low end of previous studies that valued each of the various services from wetlands that can be quantified, such as fisheries, flood control, and water purification (e.g. Gosselink et al. 1974; Farber and Costanza 1987). This assumption is almost certainly too low because it does not consider the various aesthetic benefits of better environmental quality. Our high assumption is based both on the upper end of previous studies and on the observation ${ }^{7}$ that wetland mitigation programs generally cost about $\$ 30,000$ per acre; this assumption is also an understatement, since the artificially created wetlands generally have a lower quality than the natural wetlands that are lost.

We also made a rough estimate of the undeveloped land that would be lost if only currently developed areas are protected. These estimates were based on the subjective assessments of real estate agents regarding the value of undeveloped land, as reported in Yohe (1990).

\section{Limitations}

The most frequently criticized aspect of our approach is that we have assumed constant wetland accretion rates. Because sea level itself can limit the rate of vertical accretion of wetlands, one might hope that accelerated sea level rise would enable wetland vertical accretion to accelerate as well. ${ }^{8}$ Although our results for the $50-\mathrm{cm}$ scenario are sensitive to this assumption, they are not particularly sensitive for the one- and two-meter scenarios: No one has suggested that wetlands could generally keep pace with sea level rising 1 to $4 \mathrm{~cm} / \mathrm{yr}$, which these scenarios imply for the second half of the 21 st century.

This is not to say that most areas would lose all their wetlands. Even in areas that are rapidly losing wetlands due to sea level rise, such as Louisiana, one can find parcels of wetlands that have kept pace with sea level. In areas with substantial sediment supplies, accelerated sea level rise simply implies that a fixed supply 
can sustain a proportionately smaller are of wetlands. Even in areas with relatively little sediment supply, the loss of wetlands due to erosion, inundation, or saltwater intrusion frees up sediment that had been previously bound up with the wetlands that are lost; this extra sediment may help to accelerate the vertical accretion of the remaining wetlands. Finally, some types of low-salinity marshes and mangroves appear to be able to sustain much larger rates of sea level rise than are prevalent today (Stevenson et al. 1990).

Although remote sensing provides greater vertical resolution than topographic maps, it requires interpretation which can cause errors. In California, for example, redwoods have a spectral signature very similar to some marsh grasses. Although we checked our interpretation against other sources such as U.S. Fish and Wildlife Service Wetland Inventory maps, detailed survey information was only available for a few sites. Nevertheless, as Table 1 shows, our estimate of current nationwide wetland acreage is fairly close to the estimate developed by the National Oceanic and Atmospheric Administration.

Our failure to consider the potential implications of alternative ways of managing river flow is a particularly serious limitation for application to Louisiana, where a wide variety of measures have been proposed for increasing the amount of water and sediment delivered to the wetlands.

Table 1

Comparison of This Study's Baseline Data for Vegetated Wetlands (1985) with NOAA Wetlands Inventory

\begin{tabular}{lccccr} 
& \multicolumn{3}{c}{ Baseline Data } & & NOAA $^{\text {a }}$ \\
\cline { 2 - 4 } \cline { 5 - 5 } Region (Sites) & $\begin{array}{c}\text { Percent of } \\
\text { Coast in Sample }\end{array}$ & $\begin{array}{c}\text { Wetland Area } \\
\text { (sq mi) }\end{array}$ & $\begin{array}{c}\text { Sampling Error } \\
\text { (sq mi) }\end{array}$ & $\begin{array}{c}\text { Wetland Area } \\
\text { (sq mi) }\end{array}$ \\
\hline Northeast (4) & 3.4 & 600 & 389 & 382 \\
Mid-Atlantic (7) & 8.6 & 746 & 245 & 2,080 \\
South Atlantic (8) & 10.1 & 3,813 & 848 & 3,679 \\
Louisiana (7) & 13.7 & 4,835 & 876 & 4,491 \\
Gulf except LA (14) & 12.2 & 3,087 & 1,169 & 3,608 \\
$\quad$ SW/W Florida (6) & 10.7 & 1,869 & 957 & NAb \\
$\quad$ Other Gulf (8) & 13.1 & 1,218 & 673 & NAb \\
West (6) & 4.9 & 64 & 45 & 195 \\
United States (46) & 9.7 & 13,145 & 2,105 & \\
\hline
\end{tabular}

NA $=$ Not applicable.

${ }^{a}$ Alexander et al. (1986) also estimate the area of tidal flats for several states; we present only the sum of their estimates for vegetated wetlands.

${ }^{b}$ We have modified the data from Alexander et al. To account for differences in the definition of coastal wetlands for North Carolina. Alexander et al. Include all wetlands in coastal counties regardless of elevation, while Park et al. excluded wetlands above $12 \mathrm{ft}$ NGVD. Because of extensive swamps above $12 \mathrm{ft}$ NGVD in North Carolina's coastal counties, Alexander et al. Found the area of coastal swamps to be 8.4 times the area of marsh, while the boundaries of the sample of Park et al. Found only 1.6 times as much. ${ }^{c}$ Standard deviation of the estimate of the sum (i.e., sample times the square root of the sample size).

Source: Alexander, C.E., M.A. Broutman, and D.W. Field. 1986. An Inventory of Coastal Wetlands of the USA. Rockville, MD: National Oceanic and Atmospheric

Administration.

We made no attempt to predict which undeveloped areas might be developed in the next century. Currently, only about one- seventh of the coastal lowlands are developed; even a low growth rate would imply substantially greater protection costs and higher land values for the currently undeveloped land. Finally, our conversion of the area of lost wetlands into dollar values is completely dependent on a few case studies that have never considered the implications of the large nationwide loss that could result from a rise in sea level. The law of diminishing returns implies that the cost to society of 50 percent of the coastal wetlands would be much greater than, for example, fifty times the cost of losing 1 percent. 


\section{Results}

In presenting results, we group the sites into seven coastal regions, as shown in Figure 7. New England, MidAtlantic, South Atlantic, South Florida/Gulf Coast Peninsula, Louisiana, Other Gulf (Texas, Mississippi, Alabama, Florida Panhandle), and Pacific Coast.

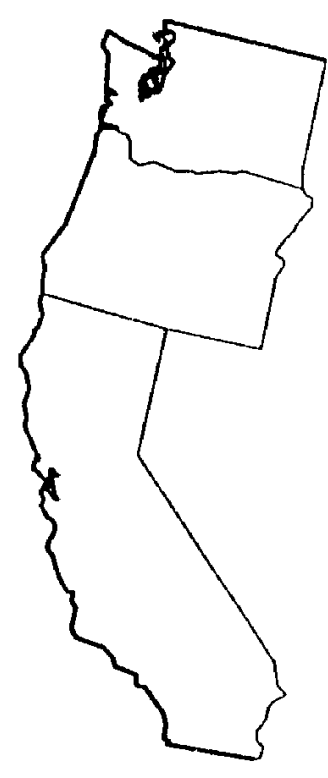

West Coast

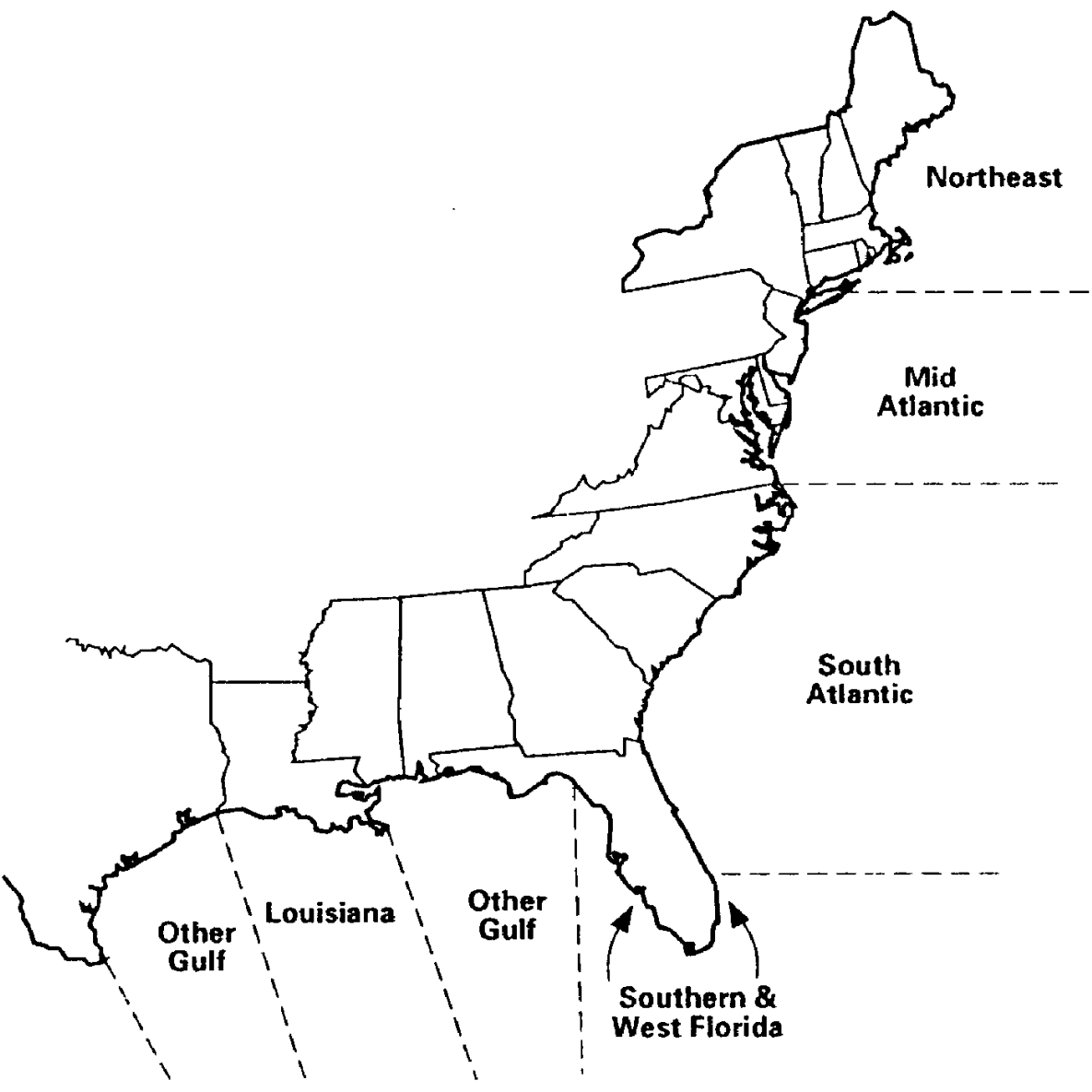

Figure 7. Coastal regions used in this study.

Figure 8 illustrates our point estimates of nationwide wetland loss for the three policy scenarios -- total, standard, and no protection. If all shorelines were protected, a one-meter rise would result in a loss of 50-82 percent of U.S. coastal wetlands, while a two-meter rise would result in a loss of 66-90 percent. If only currently developed areas are protected, the losses would be 29-69 percent and 61-80 percent for the one and two meter scenarios. Table 2 provides regional detail for the one-meter scenario; Table 3 provides nationwide results for all three scenarios. The greatest losses

of wetlands would be in the southeast, which currently has 85 percent of U.S. coastal wetlands; for a one meter rise 90-95 percent of the loss would take place in this region, 40-50 percent in Louisiana alone. By contrast, neither the northeast nor the west ${ }^{9}$ would lose more than 10 percent of their wetlands if only currently developed areas are protected. Except for the northeast, no protection results in only slightly lower wetland loss than protecting only densely developed areas. 


\section{Protect All Shores}

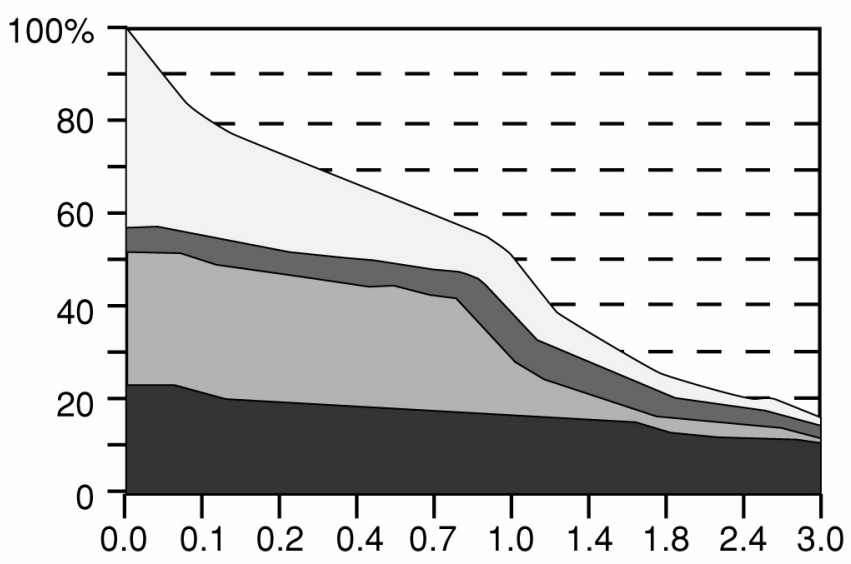

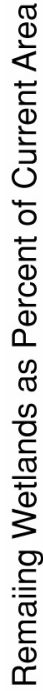

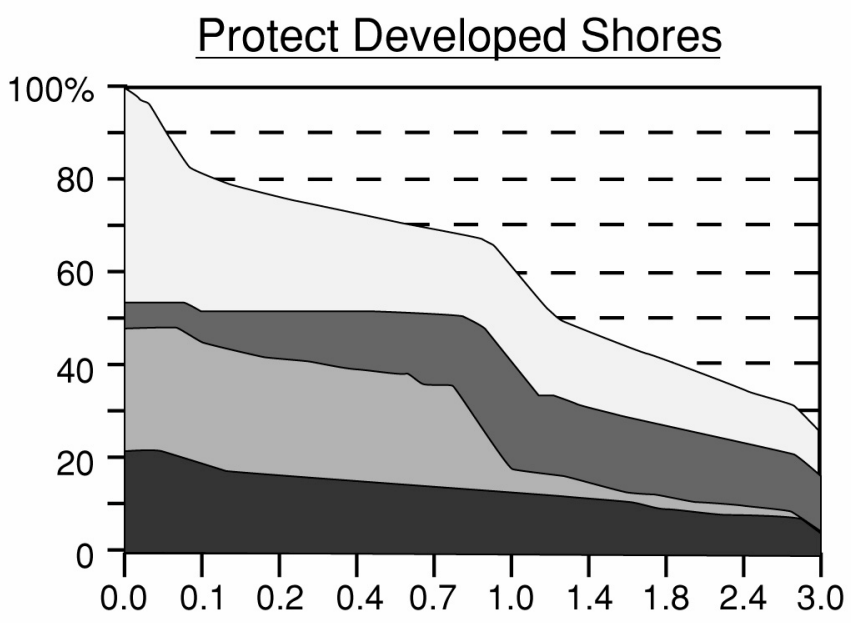

No Protection

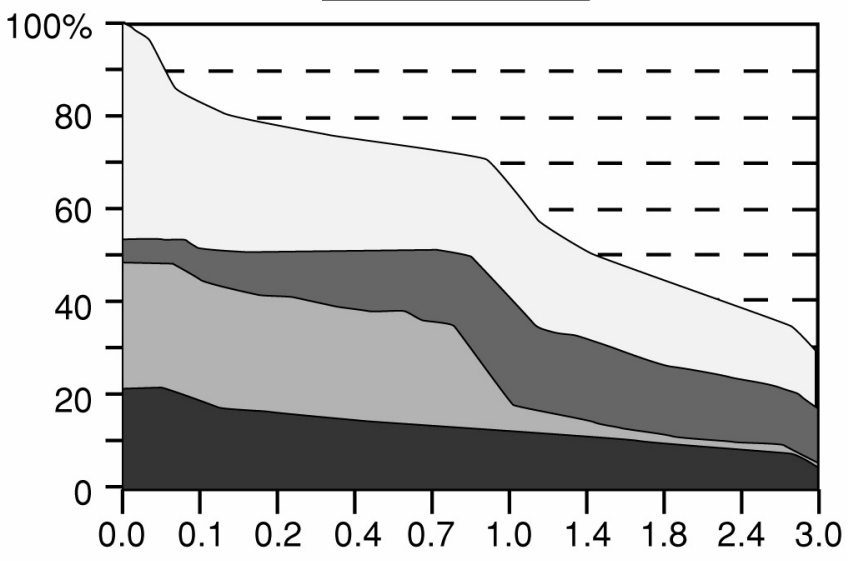

Sea Level Rise (meters)

Figure 8. Decline in wetland area by 2100 for three shoreline protection scenarios. 
Table 2

Regional and National Wetland Losses for the Trend and 1.0 Meter Sea Level Rise Scenarios (percent loss of current area)

\begin{tabular}{|c|c|c|c|c|c|}
\hline \multirow[b]{2}{*}{ Region } & \multirow{2}{*}{$\begin{array}{c}\text { Current } \\
\text { Wetland Area (sq mi) }\end{array}$} & \multirow{2}{*}{$\frac{\text { Trend }}{\text { Standard }^{b}}$} & \multicolumn{3}{|c|}{ 1.0 Meter } \\
\hline & & & Total $^{b}$ & Standard $^{b}$ & None $^{a}$ \\
\hline Northeast & 600 & 7 & 16 & 10 & $1^{a}$ \\
\hline Mid-Atlantic & 746 & -5 & 70 & 46 & 38 \\
\hline South Atlantic & 3,814 & -2 & 64 & 44 & 40 \\
\hline $\begin{array}{l}\text { South/Gulf } \\
\text { Coast of Florida }\end{array}$ & 1,869 & -8 & 44 & $8^{a}$ & $7^{a}$ \\
\hline Louisiana $^{d}$ & 4,835 & 52 & 85 & 85 & 85 \\
\hline $\begin{array}{l}\text { FL panhandle, } \\
\text { AL, MS, and TX }\end{array}$ & 1,218 & 22 & 85 & 77 & 75 \\
\hline West $^{b}$ & 64 & -111 & 56 & -688 & -809 \\
\hline United States & 13,145 & 17 & 66 & 49 & 50 \\
\hline $\begin{array}{c}\text { Confidence Intervals } \\
95 \% \text { Low } \\
95 \% \text { High }\end{array}$ & - & $\begin{array}{r}9 \\
25\end{array}$ & $\begin{array}{l}50 \\
82\end{array}$ & $\begin{array}{l}29 \\
69\end{array}$ & $\begin{array}{l}26 \\
66\end{array}$ \\
\hline
\end{tabular}

${ }^{a}$ Results are not statistically significant; sampling error exceeds estimate of wetlands lost.

${ }^{b}$ This anomalous result is from small sample size. The impact on the nationwide results is negligible. [But no one should take this estimate as a serious estimate of the impact of sea level rise on this region.]

${ }^{c}$ Total protection refers to all shores being diked or bulkheaded; standard protection refers to only currently developed areas being protected.

${ }^{d}$ An evaluation of the management options currently contemplated for Louisiana (e.g., restoring natural deltaice processes) was outside the scope of this study.

Table 3

National Wetland Losses By the Year 2100 (percent of current area)

\begin{tabular}{lcccc}
\hline & Baseline & $50 \mathrm{~cm}$ & $100 \mathrm{~cm}$ & $200 \mathrm{~cm}$ \\
\hline No Protection: & & & & 52 \\
Best Estimate & NC & 30 & 50 & 29 \\
$\quad$ 95\% Low CI & NC & 17 & 26 & 76 \\
95\% High CI & & 43 & 66 & 56 \\
Standard Protection: & 17 & 32 & 49 & 33 \\
$\quad 9$ & 20 & 29 & 80 \\
Best Estimate & 25 & 45 & 69 & 78 \\
95\% Low CI & & & 66 & 66 \\
Total Protection: & NC & 50 & 50 & 90 \\
Best Estimate & NC & 38 & 82 & \\
95\% Low CI & NC & 61 & & \\
$95 \%$ High CI & & & & \\
\end{tabular}

$\mathrm{NC}=$ Not calculated. 
Figure 9 illustrates our projections of the inundation of dry land for the seven coastal regions. If shorelines retreat naturally, a one meter rise would inundate 20,000 square kilometers (7,700 square miles) of dry land, an area thesize of Massachusetts; rises of 50 and $200 \mathrm{~cm}$ would result in losses of 13,000 and 31,000 square kilometers (5,000 and 12,000 square miles), respectively. Seventy percent of the losses would occur in the southeast, particularly Florida, Louisiana, and North Carolina; the eastern shores of Chesapeake and Delaware Bays would also loseconsiderable acreage. Table 4 provides estimates of the value of wet and dry land that might be lost is currentlydeveloped areas are protected.
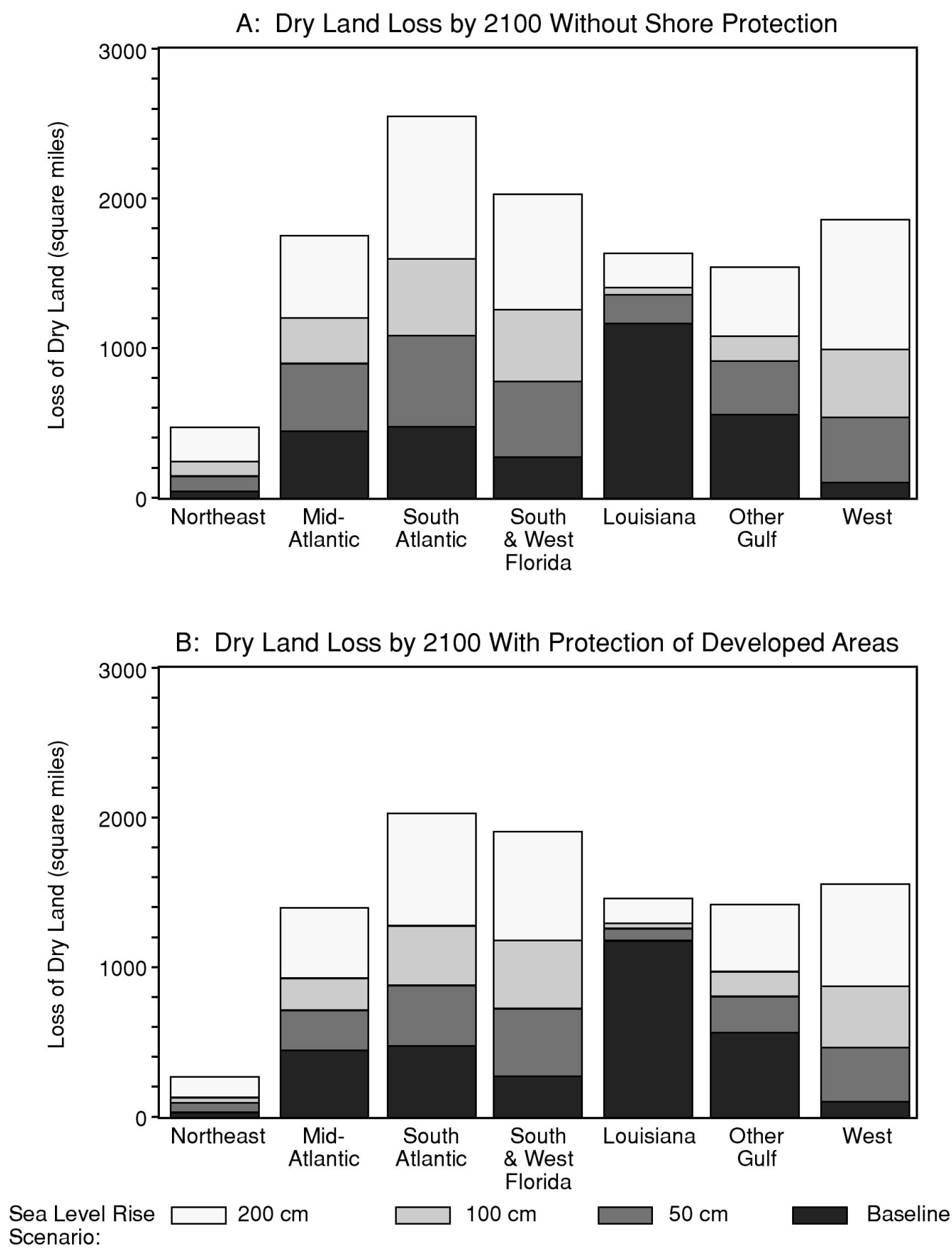

Figure 9. Dry land loss by 2100 . 
Table 4

Value of Lost Dry and Wetland By the Year 2100 (billions of dollars)

\begin{tabular}{|c|c|c|c|c|}
\hline & Baseline & $50 \mathrm{~cm}$ & $100 \mathrm{~cm}$ & $200 \mathrm{cn}$ \\
\hline \multicolumn{5}{|l|}{ Wetlands } \\
\hline Best Estimate & 15.0 & 31.2 & 47.5 & 53.0 \\
\hline Low & 5.2 & 11.5 & 17.5 & 19.5 \\
\hline High & 43.1 & 82.4 & 128.5 & 143.7 \\
\hline \multicolumn{5}{|c|}{ Undeveloped Dry Land } \\
\hline Best Estimate & 12.7 & 23.5 & 45.9 & 74.6 \\
\hline Low & 5.8 & 12.8 & 20.6 & 28.6 \\
\hline High & 18.5 & 34.3 & 71.2 & 120.6 \\
\hline \multicolumn{5}{|c|}{ Developed Dry Land Used for Building Dikes } \\
\hline Best Estimate & 0.0 & 17.7 & 25.6 & 39.3 \\
\hline Low & 0.0 & 9.5 & 13.7 & 21.6 \\
\hline Estimate & 0.0 & 33.0 & 47.8 & 73.5 \\
\hline
\end{tabular}

Note: Calculations are based on the current level of development and on the assumption that currently developed areas will be protected.

\section{Cost of Protecting Currently Developed Shores along Sheltered Waters}

\section{Methods}

Our approach here was to develop cost estimates ${ }^{10}$ for protecting six index sites and extrapolate those estimates to the other sites in the sample based on the total amount of developed shoreline to be protected and the portion of the protected area threatened with inundation.

The six index sites were metropolitan New York; Long Beach Island, New Jersey; Dividing Creek, New Jersey; metropolitan Miami; Corpus Christi, Texas; and parts of San Francisco Bay. Because our resources were not sufficient estimate the costs of shore-protection strategies for several sea level scenarios, we did so only for the 2-meter scenario, (and interpolated for the other scenarios, as we describe below).

Our assessments of the index sites assumed that developed areas below the 10-ft (NGVD) contour would require protection. Because contours are only available in 5-ft increments, this assumption was a computational necessity. Nevertheless, it is fairly reasonable: with a 2-meter rise, the contour would only be about $60 \mathrm{~cm}$ above mean sea level and hence very close to spring high tide. ${ }^{11}$ Levees were assumed to cost $\$ 1.6$ million per kilometer ( $\$ 500$ per linear foot) (Sorensen et al., 1984). As an alternative, we considered protection with bulkheads, whose cost is only $\$ 0.42$ million per kilometer ( $\$ 130$ per foot) (Sorensen et al., 1984). In the case of areas that already have bulkheads, we netted out the costs that would be incurred without sea level rise due to routine replacement, using the standard engineering assumption that that bulkhead costs increase with bulkhead height raised to the 1.5 power. In cases where the area requiring protection is isolated and connected to higher ground by low-lying roads, we estimated the cost of raising the elevation of the roadway. In areas that are too lightly developed to warrant protection, we estimated the cost of moving buildings assuming a cost of $\$ 10,000$ per structure.

Developing the nationwide estimates involved two steps: extrapolating the index sites to the entire sample, which gave us an estimate for the 2-meter scenario, and interpolating the results for each site for the 50- and $100-\mathrm{cm}$ scenarios. The first step required us to estimate the total length of shorelines that would require bulkheads or levees, the total length of roads that would have to be rebuilt, and the number of structures that would be moved. We used the digitized maps described above to estimate shoreline length, assuming that the ratio actual shoreline to digitized shoreline would be the same for the rest of the sample as it had been for the 6 index sites. We calculated the amount of roads that had to be rebuilt and structures to be moved by fitting 
regression equations that expressed those variables as functions of the amount of low-lying land that is developed and the slope of the land, both of which were available from the digitized maps.

We then interpolated for the 50 and $100 \mathrm{~cm}$ scenarios. The cost estimates assumed that the fraction of shoreline protected by levees would correspond to the fraction of lowland in the particular site that was inundated, and that the remainder of protected shorelines would be bulkheaded. We interpolated unit protection costs on the assumption that costs rise with the 1.5 power of the height of the structures. Finally, we use Yohe's (1990) data for the average value of vulnerable land in developed areas $(\$ 91,000$ to 266,000 per acre) to estimate the value of the land that would be required to build the necessary dikes, assuming that the dikes and related infrastructure average 9 meters ( 30 feet) wide.

\section{Limitations}

This task is almost certainly the least accurate part of our assessment. Only one of the index-site studies involved a visit to the site. Unit-cost estimates were based on the literature, not site-specific designs that take into consideration wave data for bulkheads and potential savings from tolerating substandard roads. Although digitized topographic and development data were considered for all 46 sites, the results depend largely on a very small sample of only six sites.

\section{Results}

Table 4 illustrates our estimates of the value of the necessary land, while Table 5 provides estimates of the cost of the dikes themselves. Unlike wetland loss, the cost of protecting developed areas from the sea would be concentrated more in the northeast than the southeast, because a much greater portion of the coast is developed in the northeast. (The southeast still accounts for a large percentage of the total costs due to its majority share of U.S. sheltered shorelines.)

Table 5

Cost of Protecting Developed Sheltered Shores Through 2100(billions of dollars)

\begin{tabular}{|c|c|c|c|c|}
\hline Region & Baseline & $50 \mathrm{~cm}$ & $100 \mathrm{~cm}$ & $200 \mathrm{~cm}$ \\
\hline Northeast & 0.41 & 2.66 & 6.22 & 22.64 \\
\hline Mid-Atlantic & 0.31 & 2.03 & 5.12 & 13.97 \\
\hline Southeast & 0.91 & 3.43 & 8.91 & 24.59 \\
\hline West & 0.04 & 0.88 & 1.82 & 4.10 \\
\hline United States & 2.00 & 9.00 & 22.07 & 65.30 \\
\hline $\begin{array}{c}\text { Confidence Inter } \\
95 \% \text { Low } \\
95 \% \text { High }\end{array}$ & $\begin{array}{l}1.20 \\
2.80\end{array}$ & $\begin{array}{r}4.98 \\
13.02\end{array}$ & $\begin{array}{l}10.82 \\
33.32\end{array}$ & $\begin{array}{r}29.60 \\
100.99\end{array}$ \\
\hline
\end{tabular}

\section{Cost of Protecting the Open Coast}

\section{Methods}

Because resources were limited, we could only consider a single technology for the entire coast. We chose the island raising approach, based on the Long Beach Island study discussed in the background section. We assumed that all developed barrier islands would be protected in this fashion, as well as a few undeveloped recreational and Louisiana's barrier islands, where shore protection is a state policy.

This task consisted of estimating (1) the cost of placing sand on the beach profile and low parts of barrier islands and (2) the cost of elevating houses and infrastructure. 
Sand Quantities. This part of the analysis required us to estimate the amount of sand each state would require and the average unit cost of sand in that state. For the former task, we employed the "raise the profile" method, which is consistent with the Bruun (1962) rule but does not require as many assumptions (Titus and Greene, 1989). This method simply states that the amount of sand required is equal to the area being raised times the rise in sea level. For small amounts of sea level rise, only the active beach profile must be raised (to curtail erosion); for larger rises, dry land must also be raised (to prevent inundation).

The only difficulty in applying this method is deciding the extent of the beach profile being raised. Hallermeier (1981) recommended that analysts calculating the amount of sand necessary for beach nourishment use the critical closure depths for significant offshore transport, which he estimated as generally about 5-7 meters on the Atlantic Cost, 4-5 meters on the Gulf Coast, and 5-10 meters along the Pacific Coast. He also estimated the closure depths for significant transport of any type, but he recommended these depths only for use in erosion calculations. Thus, in the peer review draft, we used bathymetric charts to estimate the distance out to sea of the closure depths for offshore transport, and topographic maps to estimate the inland distance of the dune crest, added the two distances, and multiplied by the shoreline length to arrive at an estimate of the area of the beach profile that needed to be raised.

In a previous publication (Titus and Greene 1989), we had noted that this procedure probably provided estimates that were too low. The closure depth and distance recommended by Hallermeier approximate the profile adjustment in a single year; should a major hurricane come along, material will be carried much further out to sea. Indeed, most cost studies of beach nourishment may be acknowledging this implicitly by also including an allowance for periodic "renourishment" projects. However, it would be inappropriate to use the normal renourishment formulas, because they generally lump the additional sand necessitated by long-term profile adjustment in with other factors that are outside the scope of this analysis (such as alongshore transport) or already included (such as post-project sea level rise).

Nevertheless, about half the reviewers of the original version of this paper suggested that its most serious flaw was that the sand quantity estimates were too low. Accordingly, we decided to call the original estimates our low scenario and develop a high scenario adapted from the Titus and Greene paper:

Low: $\operatorname{Sand}_{\mathrm{t}}=\mathrm{A} * \mathrm{SLR}_{\mathrm{t}}$ High: $\operatorname{Sand}_{\mathrm{t}}=\mathrm{A} * \mathrm{SLR}_{\mathrm{t}}-\mathrm{B} * \mathrm{SLR}_{\mathrm{t}-1}+\mathrm{c} * \operatorname{Sand}_{\mathrm{t}-1 \text {, }}$

where the asterisk "*" denotes multiplication, $B=A *\left(1-(1-c) *\left(d_{i} / d_{1}\right)^{1.5}\right)$ and $A$ is the ratio of the horizontal and vertical extents of the beach profile, $1 /(1-\mathrm{c})$ is the "e-folding" time for long-term profile adjustment in years, and $\left(\mathrm{d}_{\mathrm{i}} / \mathrm{d}_{1}\right)^{1.5}$ is an estimate of the ratio of the profile lengths from the two closure depths suggested estimated by Hallermeier, using the assumption that profiles follow the shape $y=x^{2 / 3}$. We then assumed that $\mathrm{c}=.96$ for the Gulf coast and .98 for the Atlantic and Pacific Coasts.

Simply put, the high scenario assumes that in the first year after a rise in sea level, the sand required to stabilize the shore is the same as the sand projected by the low scenario; but in equilibrium, the required sand will be 6.0, 3.5, and 15.7 times as great for the Atlantic, Gulf, and Pacific Coasts, based on the alternative estimates of the profile length. The values of $c$ imply that 90 percent of the adjustment will occur in 57 years for the Gulf and 114 years elsewhere.

Sand would also be required for elevating dry land. We assumed that after the first foot of sea level rise, portions of coastal barrier islands below $152 \mathrm{~cm}(5 \mathrm{ft} \mathrm{NGVD})$ would be raised with the sea, and that other parts of coastal barriers would be raised after the third foot.

We employed this procedure for every developed recreational beach from Delaware Bay to the mouth of the Rio Grande, as well as the state of California. For the rest of the coast, we picked one representative site for each state; we then extrapolated the individual sites to the rest of the state based on the length of the developed shoreline. 
Sand Costs. For both of the sand quantity formulas, we developed high and low cost estimates for each state, based on inventory surveys by the Corps of Engineers and state agencies contemplating beach nourishment projects. ${ }^{13}$ The low estimates were based on the assumption that unit sand costs remain constant, while the high estimates assume that unit costs increase as the least expensive nearshore deposits are exhausted and it becomes necessary to go farther out to sea or mine lower-quality deposits.

For the most part, existing inventories identify sufficient sand for the projects that officials are currently contemplating, but not the far greater quantities that would be necessary to address a substantial rise in sea level. Therefore, we were unable to specify separate reliable sand cost functions for each state in developing our high scenario. However, sufficient sand has been identified for such a cost function for Florida's Atlantic coast, illustrated in Table 6.

Therefore, we calculated sand costs for each state by assuming that costs would escalate by the same pattern (scaling for the length of the state's shore); i.e. we considered current differences in sand costs for various states but assumed that those differences would not change as sea level rises.

Table 6

Cost Function For Florida's Atlantic Coast

\begin{tabular}{ccc}
\hline $\begin{array}{c}\text { Distance Offshore } \\
(\mathrm{mi})\end{array}$ & $\begin{array}{c}\text { Available Sand } \\
\left(\text { (millions yards }^{3}\right)\end{array}$ & $\begin{array}{c}\text { Unit Cost } \\
\left(\$ / \text { ard }^{3}\right)\end{array}$ \\
\hline $0-1$ & 66 & 4 \\
$1-2$ & 87 & 5 \\
$2-3$ & 122 & 6 \\
$3-4$ & 48 & 7 \\
$4-5$ & 0 & 10 \\
$5+$ & plenty & 10
\end{tabular}

Source: Sand quantities are based on surveys by the Corps of Engineers. Unit sand cost estimates up to five miles assume that dredges pump the sand onto the shore and use the generally accepted rule-of-thumb that each additional mile offshore adds $\$ 1 /$ yard ${ }^{3}$ for the additional booster pumps. For all distances greater than five miles, barges and dump trucks would be employed at a cost of $10 /$ yard $^{3}$.

Cost of Raising Land and Structures. Estimating the cost of elevating roads and structures required us to obtain estimates of (1) the area of developed land that would be elevated, (2) the density of structures, and (3) unit cost factors. Because the only case study to address this issue was the study of Long Beach Island (Weggel et al., 1989), this part of our analysis consisted primarily of extrapolating that case study to other barrier islands based on our estimates of bay and ocean-side areas and Census data on building density (Bureau of the Census, 1980).

Because Census data for barrier islands is limited, this part of the analysis had to be conducted at a greater level of aggregation than the portion on sand costs; we divided the coast into Northeast/Mid Atlantic, South Atlantic, and Gulf, ignoring the west coast where there are no barrier islands. For each group, we randomly sampled coastal towns for which Census data is available, and calculated the density of structures.

As Table 8 shows, our extrapolation equations assumed that the cost for elevating structures could be described as

$$
\text { Cost }_{\text {slr }}=a_{\text {slr }} * \text { Shoreline_length }+b_{\text {slr }} \text { *buildings }
$$

where the number of buildings is area multiplied by housing density. Our rationale was that the Long Beach Island study had found that most of the costs were associated with roads and utilities. We derived parameters for this equation by assuming that the length of primary roads is equal to the length of the island and that secondary road mileage is proportional to the number of buildings, with constants of proportionality and the cost of responding to 50,100, and $200 \mathrm{~cm}$ rises in sea level based on Long Beach Island. For the 50-cm scenario, we assumed that only the low bay sides would be raised; for the $200 \mathrm{~cm}$ scenario, we assumed that entire islands would be raised. However, for the $100-\mathrm{cm}$ scenario, we developed two equations to acknowledge 
Originally in Coastal Management, Volume 19, pp. 171-204 (1991)

that we are not certain whether communities would elect to raise land currently above the 5-ft NGVD contour. On one hand, much of this land is about 3 meters ( $10 \mathrm{ft}$ ) above NGVD, and hence would still be above sea level; on the other hand, with a typical spring tide range of $200 \mathrm{~cm}$ historic sea level rise, and future subsidence, land at the $10 \mathrm{ft}$ NGVD contour would only be about $60 \mathrm{~cm}$ above spring high tide, which would leave the island vulnerable during severe storms.

\section{Limitations}

Because state-specific inventories and sand-cost assessments have been conducted, our estimates of future dredging costs are probably much more accurate than our estimates of the cost of elevating structures. Nevertheless, both sets of estimates faced important data and model limitations.

Sand Quantities. Because of its geometric simplicity, the "raising the profile" method of estimating the necessary sand is conceptually appealing. But one must decide whether to use a short or long-term profile. Communities could delay much of the costs by placing most of the sand on the upper part of the beach (Titus, 1984). By using the annual storm to determine the profile, the low scenario fails to account for the fact that the success of the project is only temporary; eventually the entire profile must be raised. The high scenario may be more realistic, but because there is no research available to estimate the likely adjustment times, we had to simply take a guess. Moreover, Hallermeier's estimates do not explicitly consider hurricanes and other rare but severe storms, which might extend the effective profile even farther out to sea. This limitation is particularly important given the possibility that hurricanes may become more severe as global temperatures rise.

Unit Costs. Both our low and high estimates assumed that the sand placed on the beach has sufficient grain size to remain within the beach system; we lacked the data to estimate the quantity that would wash away. Moreover, both estimates assume that developments in technology do not change the costs. Although improvements in technology and economies of scale have the potential to lower the cost, future increases in energy prices may offset these economies. Finally, we assumed that the same sources would be employed for raising the active beach profile as for raising dry land; low-cost material unsuitable for the beach may prove acceptable for raising building lots.

Our procedure for extrapolating the cost escalation in Florida to the rest of the nation is even more suspect. In many areas, sand costs are currently higher because they already have to go farther out to sea, suggesting a greater scarcity, which might result in the escalation being greater; in other areas, there may be ample sand close to the shore. We assumed that tidal deltas would not be mined for sand. ${ }^{14}$

Costs of Elevating Structures. The Bureau of the Census does not provide data on the number of structures for various barrier islands; one must infer the density based on (1) data for jurisdictions that are entirely on coastal barriers, and (2) by assuming that communities that include both mainland and barrier islands have a uniform density. Moreover, our analysis treated all structures the same, even though hotels or apartments would be far more costly to elevate than the single family homes that dominate on Long Beach Island. Finally, the extrapolation of a single community to the entire nation implies that our estimates are valid only if that community's costs are "typical", a condition that can only be verified by examining other communities.

\section{Results}

Table 7 shows our estimates by state of the dredging costs that would accompany the various scenarios of future sea level rise. A total of 3,100 kilometers (1,920 miles) of shoreline would be nourished. An area of 7,233 square kilometers ( 2753 square miles) would potentially have to be raised, one quarter of this after the first foot of sea level rise. ${ }^{15}$ One-half to two-thirds of the nationwide cost would be borne by four southeastern states: Texas, Louisiana, Florida, and South Carolina. However, much of the costs for Texas result from the width of its barrier islands; if urban centers such as Galveston are protected with levees, dredging costs for that state could be less than half as great as shown here. 
Table 7a. Cumulative Cost of Sand to Protect the United States' Open Coast (Low Scenario for Required Sand)

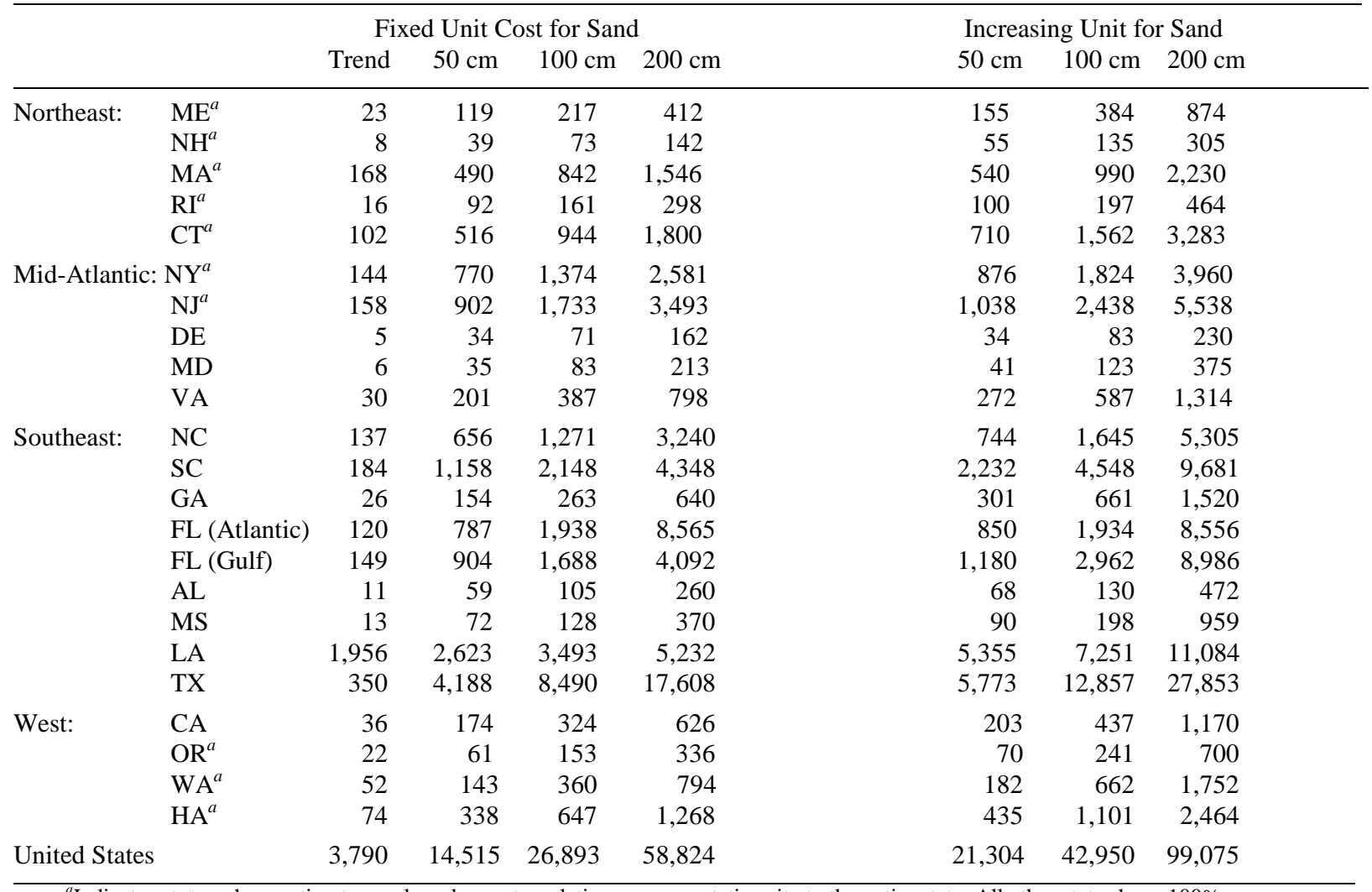

${ }^{a}$ Indicates states where estimate was based on extrapolating a representative site to the entire state. All other states have $100 \%$ coverage.

Table 7b. Cumulative Cost of Sand to Protect the United States' Open Coast (High Scenario for Required Sand)

\begin{tabular}{|c|c|c|c|c|c|c|c|}
\hline & & Fixed & nit Cost & or Sand & Increasi & g Unit Co & st for Sand \\
\hline & & $50 \mathrm{~cm}$ & $100 \mathrm{~cm}$ & $200 \mathrm{~cm}$ & $50 \mathrm{~cm}$ & $100 \mathrm{~cm}$ & $200 \mathrm{~cm}$ \\
\hline Northeast: & $\mathrm{ME}^{a}$ & 427 & 751 & 1397 & 914 & 1722 & 3339 \\
\hline & $\mathrm{NH}^{a}$ & 139 & 253 & 480 & 304 & 588 & 1155 \\
\hline & $\mathrm{MA}^{a}$ & 1786 & 2954 & 5291 & 2650 & 4709 & 8827 \\
\hline & $\mathrm{RI}^{a}$ & 332 & 560 & 1015 & 531 & 986 & 1897 \\
\hline & $\mathrm{CT}^{a}$ & 1851 & 3266 & 6097 & 3383 & 6214 & 11876 \\
\hline Mid-Atlantic: & NYa & 2776 & 4775 & 8772 & 4300 & 7826 & 14879 \\
\hline & $\mathrm{NJ}^{a}$ & 2576 & 4304 & 7851 & 3923 & 6970 & 13228 \\
\hline & $\mathrm{DE}$ & 110 & 195 & 381 & 143 & 292 & 616 \\
\hline & $\mathrm{MD}$ & 125 & 230 & 471 & 206 & 415 & 897 \\
\hline & VA & 739 & 1220 & 2220 & 1209 & 2049 & 3801 \\
\hline Southeast: & $\mathrm{NC}$ & 2348 & 4292 & 8933 & 3648 & 7259 & 15877 \\
\hline & $\mathrm{SC}$ & 4236 & 7018 & 12794 & 9421 & 15910 & 29388 \\
\hline & GA & 558 & 956 & 1803 & 1316 & 2310 & 4428 \\
\hline & FL (Atlantic) & 2306 & 4130 & 9118 & 4306 & 8864 & 21334 \\
\hline & FL (Gulf) & 2297 & 4090 & 8508 & 4492 & 8973 & 20019 \\
\hline & $\mathrm{AL}$ & 161 & 282 & 585 & 224 & 526 & 1283 \\
\hline & MS & 197 & 344 & 766 & 412 & 880 & 2224 \\
\hline & LA & 6768 & 8792 & 12840 & 14466 & 18919 & 27826 \\
\hline & $\mathrm{TX}$ & 8483 & 15143 & 28983 & 12838 & 23818 & 46637 \\
\hline West: & $\mathrm{CA}$ & 1546 & 2770 & 5217 & 3477 & 6536 & 12654 \\
\hline & $\mathrm{OR}^{a}$ & 422 & 1081 & 2399 & 916 & 2563 & 5858 \\
\hline & $\mathrm{WA}^{a}$ & 998 & 2556 & 5672 & 2256 & 6151 & 13941 \\
\hline & $\mathrm{HA}^{a}$ & 2869 & 5303 & 10171 & 5994 & 11348 & 22058 \\
\hline United States & & 44,059 & 75,267 & 141,771 & 81,334 & 145,834 & 284,049 \\
\hline
\end{tabular}

\footnotetext{
${ }^{a}$ Indicates states where estimate was based on extrapolating a Representative site to the entire state. All other states have $100 \%$ coverage.
} 
Table 8 illustrates our estimates of the cost of elevating roads and structures. For a 50-cm rise, Gulf Coast barrier islands account for over 50 percent of the $\$ 32$ billion cost, largely due to their lower elevations. By contrast, for a 2-meter rise, the Mid-Atlantic and Northeast would account for over 50 percent of the \$286 billion cost because they are on average the most densely developed.

Table 8

Cost of Elevating Roads and Structures

\begin{tabular}{|c|c|c|c|c|c|}
\hline \multicolumn{2}{|l|}{ Data } & Gulf & $\begin{array}{c}\text { South } \\
\text { Atlantic }\end{array}$ & $\begin{array}{c}\text { Mid-Atlantic } \\
\text { and Northeast } \\
\text { Shoreline } \\
\text { (565522 mi) }\end{array}$ & $\begin{array}{c}\mathrm{USA}^{a} \\
\text { Shoreline } \\
(5111598 \mathrm{mi})\end{array}$ \\
\hline \multicolumn{2}{|l|}{ Bayside Area $\left(\mathrm{mi}^{2}\right)$} & 543 & 72 & 90 & 705 \\
\hline \multirow{2}{*}{\multicolumn{2}{|c|}{$\begin{array}{l}\text { Oceanside Area }\left(\mathrm{mi}^{2}\right) \\
\left.\text { Building Density (units } / \mathrm{mi}^{2}\right)\end{array}$}} & 975 & 501 & 612 & 2088 \\
\hline & & \multicolumn{4}{|c|}{ Building Density (units/mi ${ }^{2}$ ) } \\
\hline \multicolumn{2}{|c|}{ Mean } & 377 & 586 & 1726 & $\mathrm{NC}$ \\
\hline \multicolumn{2}{|c|}{ Standard Deviation } & 282 & 469 & 1177 & $\mathrm{NC}$ \\
\hline \multicolumn{2}{|c|}{ Standard Deviation of Mean } & 85 & 130 & 294 & $\mathrm{NC}$ \\
\hline \multicolumn{6}{|c|}{ Cost (billions of dollars) } \\
\hline \multicolumn{2}{|l|}{$50 \mathrm{~cm}$} & 17.4 & 4.2 & 10.8 & $32.4+3.5$ \\
\hline \multicolumn{2}{|l|}{$100 \mathrm{~cm}$} & 32.7 & 7.8 & 21.6 & $62.1+6.6$ \\
\hline \multicolumn{2}{|c|}{$100 \mathrm{~cm}$ (alternative cost) } & 51.6 & 34.2 & 84.3 & $170.1+17.6$ \\
\hline \multicolumn{2}{|l|}{$200 \mathrm{~cm}$} & 81.6 & 54.3 & 150.3 & $286.2+29.6$ \\
\hline \multicolumn{6}{|l|}{ Cost Equations ${ }^{b}$} \\
\hline Cost $(50 \mathrm{~cm})$ & 6,58 & \multicolumn{4}{|c|}{$6,580,400 *$ Length $*$ Bayside_Area/Area $+65,947 *$ Bayside_Area $*$ Density } \\
\hline Cost $(100 \mathrm{~cm})$ & 12,3 & \multicolumn{4}{|c|}{$12,327,000 *$ Length $*$ Bayside_Area/Area $+123,542$ Bayside_Area $*$ Density } \\
\hline \multicolumn{6}{|l|}{ Alternative } \\
\hline Cost $(100 \mathrm{~cm})$ & 6,90 & \multicolumn{4}{|c|}{$6,903,000 *$ Length $+69,518 *$ Area $*$ Density } \\
\hline Cost $(200 \mathrm{~cm})$ & 10,9 & \multicolumn{4}{|c|}{$10,952,000 *$ Length $+110,287 *$ Area $*$ Density } \\
\hline
\end{tabular}

\section{Summary and Conclusions}

We estimate that shoreline retreat from a one-meter rise in sea level would cost the United States $\$ 270$ to $\$ 475$ billion dollars. Like all cost estimates involving unprecedented activities, our estimates ignore the impacts we could not readily quantify and those we can not foresee, and hence, are almost certainly too low. But policymakers are accustomed to "soft" estimates, and we see no reason to believe that our underestimates are any worse than the norm.

Table 9 summarizes our calculations. Thirty six thousand square kilometers (fourteen thousand square miles) of land could be lost from a one-meter rise, with wet and dry land each accounting for about half the loss. For a few hundred billion dollars, fifteen hundred square kilometers (six to seven hundred square miles) of currently developed land could be protected, but the loss of coastal wetlands would be that much greater. 
Table 9

Summary of Nationwide Results (billions of dollars unless otherwise stated)

\begin{tabular}{|c|c|c|c|c|}
\hline & Baseline & $50 \mathrm{~cm}$ & $100 \mathrm{~cm}$ & $200 \mathrm{~cm}$ \\
\hline \multicolumn{5}{|l|}{ If No Shores Are Protected } \\
\hline Dryland Lost (sq mi) & $\mathrm{NC}$ & $3315-7311$ & $5123-10330$ & 8191-15394 \\
\hline Wetlands Lost $(\%)$ & $\mathrm{NC}$ & $17-43$ & $26-66$ & $29-76$ \\
\hline \multicolumn{5}{|c|}{ If Developed Areas Are Protected } \\
\hline Dryland Lost (sq mi) & $1470-4686$ & $2200-6100$ & $4100-9200$ & $6400-13500$ \\
\hline Wetlands Lost (\%) & $9-25$ & $20-45$ & $29-69$ & $33-80$ \\
\hline Value of Lost Land & & $52-130$ & $86-212$ & $112-297$ \\
\hline Wetlands & $5-43$ & $11-82$ & $17-128$ & $19-144$ \\
\hline Undeveloped Land & $6-19$ & $13-34$ & $21-71$ & $29-121$ \\
\hline Land for Dikes & $16-47$ & $9-33$ & $14-48$ & $22-74$ \\
\hline Cost of Coastal Defense & 4 & $55-123$ & $143-305$ & $402-645$ \\
\hline \multicolumn{5}{|l|}{ Open Coast: } \\
\hline Sand & 4 & $15-81$ & $27-146$ & $59-284$ \\
\hline Elevate Structures & 0 & $29-36$ & $62-170$ & $257-316$ \\
\hline \multicolumn{5}{|l|}{ Sheltered Shores } \\
\hline Dike Construction & 0 & $5-13$ & $11-33$ & $30-101$ \\
\hline $\begin{array}{l}\text { Total Cost of Inundation } \\
\text { and Erosion }\end{array}$ & $20-51$ & $128-232$ & $270-475$ & $576-880$ \\
\hline If All Shores Are Protected & & & & \\
\hline Wetlands Lost $(\%)$ & $\mathrm{NC}$ & $38-61$ & $50-82$ & $66-90$ \\
\hline
\end{tabular}

N.C. $=$ Not Calculated.

Our estimates are optimistically low because we assume that it will only be necessary to protect areas that are developed today, that is, about $15 \%$ of U.S. coastal lowlands. If development continues and (1) we protect those areas as well, the economic impact could be far greater because more dikes would be necessary and wetland loss would be greater. If development continues but (2) we eventually abandon those areas, the wetland loss will be the same as assumed in this article, but there could be tremendous loss of homes, offices, and infrastructures as the abandonment takes place. But (3) prohibiting coastal development would also have costly impacts on the economy, which we would have to add. Thus, this article is a severe under-estimate of the nationwide cost of sea level rise unless we implement a means of abandoning low-lying areas at little or no cost. ${ }^{16}$

At the national level, protecting developed coastal areas appears to be cost-effective. The cumulative cost would be spread over 100 years; even at the end of the century, the annual cost of protection on barrier islands would be about $\$ 2000$ for a quarter-acre lot—hardly a welcome prospect for coastal property owners but nevertheless one well worth bearing in order to maintain the property. The cost of protecting developed mainland areas would be only about one-tenth as great.

The fact that it may be cost-effective to protect property does not necessarily imply that it would be in the interest of society to do so. We must also consider the loss of natural shorelines and coastal wetlands that would result. Our results suggest that up to a point, the objectives of protecting wetlands and coastal property may be compatible. Clearly, abandoning densely developed areas goes beyond that point; it would increase the areas of surviving wetlands by only 5 to $10 \%$, but at great cost. By contrast, limiting coastal protection to areas that are already densely developed (and allowing currently undeveloped areas to flood) would increase the area of surviving coastal wetlands by 40 to $100 \%$, depending on how much the sea rises.

Moreover, estimates in areal losses understate the differences in environmental impacts for the various policy options. Although a substantial loss would occur even if deeloped areas were abandoned, most of today' wetland shorelines would still have wetlands; the strip would simply be narrower. By contrast, protecting all 
mainland shorelines could result in wetlands being confined to a small number of isolated reserves, a situation that humanity has already imposed on many terrestrial species.

Our results are consistent with the hypothesis of a 1987 study by the National Academy of Engineering that shore protection will be cost-effective for most developed areas (NRC 1987). From the perspective of civil engineers, that study concluded that little action is necessary today because shore protection structures can be erected rapidly compared with the rate of sea level rise. However, the speed with which communities could build these structures is small comfort to the birds and fish whose habitat would be destroyed by doing so.

Sea level rise if an urgent issue for coastal environmental planners for the very reason that it lacks urgency for directors of public works. If environmentalists do not lay the necessary paperwork today to institutionalize a gradual abandonment of the coastal plain as sea level rises, the public will almost certainly call upon engineers to protect their homes in the years to come.

\section{Notes}

1. Mean sea level refers to the average water level over the course of a year.

2. A critical question requiring research is: How rapidly is "too rapidly"? If salinity is low, mangroves may be able to keep up with almost any rate of sea level rise. In deltas and other areas with large sediment supplies, at least some of the marshes can keep up with a 1-2 $\mathrm{cm} / \mathrm{yr}$ rise. In this case, a net loss will still occur, since there is a fixed sediment supply (e.g. a threefold increase in the rate of relative sea level rise would eventually cut the area of the delta by a factor of three).

3. A 15-year storm is a storm whose flood levels have a probability of $1 / 15$ of being exceeded in any given year.

4. In many estuaries, the direct environmental impact of saltwater intrusion would probably be greater than shoreline retreat, especially in the short run. However, the upstream penetration of the salt front due to sea level rise can generally be offset by relatively modest releases of freshwater from dams or river diversion structures, at a modest cost compared with abandoning developed areas, erecting dikes, and other options investigated by this report.

5. Assuming that storm frequency does not change, which is appropriate for an analysis designed only for sea level rise. Note, however, that hurricanes require a water temperature of $79^{\circ} \mathrm{F}$ to form; thus, as global temperatures warm, hurricanes may become more frequent (Emmanuel, 1987).

6. For example, if the tidal range is 4 feet, mean high water is 2 feet above sea level. If an area appears to be low marsh, we would assume that elevations are uniformly distributed between 0 and $2 \mathrm{ft}$. MSL (which would generally be 0.5 to $2.5 \mathrm{ft} \mathrm{NGVD}$, since sea level has risen 6 inches since NGVD was established).

7. Dennis King, University of Maryland.

8. Edward T. LaRoe, U.S. Fish and Wildlife Service, Washington, D.C., Personal communication.

9. The anomalous west coast results were caused by a small sample size. However, given the west coast's relatively small share of the nation's wetlands, the impact on the nationwide results are small.

10. All costs are in constant 1988 dollars.

11. In most locations, sea level has risen 15-20cm since NGVD was established in 1929, and an additional 20-25 cm of subsidence could be expected through the year 2100 .

12. For the index sites, we estimated shoreline length using a planimeter and on a USGS quadrangle.

13. The last national assessment of shore erosion and the planning implications was undertaken by the U.S. Army Corps of Engineers in 1971. Their national survey, based on District Corps office reports, indicated the prevalence of shore erosion. In addition, there are numerous site specific reports and information available for various locales (we referenced well over one hundred). These data were assembled and analyzed to extract information pertinent to the study. Corps district personnel and State Coastal Zone Management (CZM) officials were also queried for any up-to-date information and insights. The CERC Inner-Continental Shelf Studies (ICON) data sets provided the information on offshore sand resources.

14. Although resorting to these sources would create erosion, the savings resulting from their proximity may be greater than the additional costs resulting from the increased erosion.

15. For the reader concerned by the apparent contradiction that the area of barrier island that must be raised would be greater than the total amount of dryland requiring protection from inundation: Most of the land being raised would be above high water even if sea level rises, but would have to be raised for flood-control purposes. Similarly, the dikes that protect the dry mainland areas threatened by inundation would also provide incidental flood protection to adjacent areas with higher elevations, but we do not explicitly estimate the area.

16. In a companion paper, Titus (1991) examines seven options for doing so. 


\section{References}

Alexander, C. E., M. A. Broutman, and D. W. Field. 1986. An inventory of coastal wetlands of the USA. Rockville, MD. National Oceanic and Atmospheric Administration.

Arrhenius, S. 1896. "On the influence of carbonic acid in the air upon the temperature on the ground." Philosophical Magazine. 41:237.

Ausubel, J. H. 1983. Historical note. Changing climate. Washington, DC: National Academy Press.

Barnett, T. P. 1984. "The estimation of "global" sea level change: A Problem of uniqueness. Journal of Geophysical Research. 89(C5):7980-7988.

Barrel, J. C. Schuchert, C. Woodruff, R. Lull, and E. Huntington. 1919. The earth and its inhabitants. New Haven, CT: Yale University Press.

Barth, M. C., and J. G. Titus, eds. 1984. Greenhouse effect and sea level rise: A challenge for this generation. New York: Van Nostrand Reinhold Company.

Bentley, C. R. 1983. West Antarctic ice sheet: Diagnosis and prognosis. In Proceedings to Carbon Dioxide Research Conference. See U.S. Department of Energy, 1983.

Bruun, P. 1962. Sea level rise as a cause of shore erosion. Journal of Waterways and Harbor Division. American Society of Civil Engineers 88:117-130.

Bureau of the Census. 1982. 1980 Census of Housing: Volume 1, Characteristics of Housing Units. Washington, DC: U.S. Department of Commerce.

Clark, J. A., and C. S. Lingle. 1977. Future sea level changes due to West Antarctic ice sheet fluctuation. Nature 269(5625):206-209.

DeSarthy, B. V. 1974. HINDU: Histogram Inspired Neighborhood Discerning Unsupervised Pattern Recognition System Huntsville, AL: NASA/Computer Sciences Corporation.

Donn, W. L., W.R. Farrand, and M. Ewing. 1962. Pleistocene ice volumes and sea-level lowering. Journal of Geology. 70:206-214.

Emmanuel, K. A. 1987. The dependence of hurricane intensity on climate. Nature. 326(6112):483-485.

Everts, C. H. 1985. Effects of sea level rise and net sand volume change on shoreline position at Ocean City, Maryland." In Potential impacts of sea level rise. See Titus, 1985.

Farber, S., and R. Costanza. 1987. The economic value of wetlands systems. Journal of Environmental Management 24:41-51.

Gornitz,V. S., S. Lebedeff, and J. Hansen. 1982. Global sea level trend in the past century. Science 215:1611-1614.

Gosselink, J. G., E. P. Odum, R. M. Pope. 1974. The value of tidal marsh. Baton Rouge: Center for Wetland Resources, Louisiana State University.

Gunter, G. 1974. An Example of Oyster Production Decline with a Change in the Salinity Characteristics of an Estuary-Delaware Bay, 1800-1973. " Proceedings of the National Shellfish Association. 65:3.

Hallermeir, R. J. 1981. A profile zonation for seasonal sand beaches from wave climate. Coastal Engineering. 4:253.

Howard, J. D., O. H. Pilkey, and A. Kaufman. 1985. Strategy for beach preservation proposed. Geotimes. 30:15.

Hughes, T. 1983. The stability of the West Antarctic ice sheet: What has happened and what will happen." In Proceedings to Carbon Dioxide Research Conference. See U.S. Department of Energy, 1983.

Hull, C. H. J., and J. G. Titus, eds. 1986. Greenhouse effect, sea level rise, and salinity in the Delaware Estuary. Washington, DC: U.S. Environmental Protection Agency.

Intergovernmental Panel on Climate Change, 1990. Scientific assessment of climate change. Blacknell, UK: UK Meteorological Office.

Kana, T. W., J. Michel, M. O. Hayes, and J. R. Jenson. 1984. The physical impact of sea level rise in the area of Charleston, South Carolina. In Greenhouse effect and sea level rise, 105-150. See Barth and Titus, 1984.

Kana, T. W., B. J. Baca, and M. L. Williams. 1986. Potential impacts of sea level rise around Charleston, South Carolina. Washington, DC: U.S. Environmental protection Agency.

Kaye, A., and E. S. Barghoorn. 1984. Lake quaternary sea level change and coastal rise at Boston, Masachusetts. Geology Society of America, Bulletin 75:63-80.

Kennett, J. P. 1982. Marine Geology. Englewood Cliffs, NJ: Prentice- Hall.

Kyper, T., and R. Sorensen. 1985. Potential impacts of selected sea level rise scenarios on the beach and coastal works at Sea Bright, New Jersey. In Coastal Zone '85. See Magoon, 1985.

Lefor, M. W., W. C. Kennard, and D. L. Civco. 1987. Relationships of salt-marsh plant distributions to tidal levels in Connecticut, USA. Environmental Management. 11(1):61-68. 
Lyle, S. D., L. E. Hickman, and H. A. Debaugh, 1988. Sea level variations in the United States, 1955-1986. Rockville, MD: National Oceanic and Atmospheric Administration.

Magoon, O. T., H. Converse, D. Miner, D. Clark, and L. T. Tobin, eds. 1985. Coastal Zone '85. New York: American Society of Civil Engineers.

Meier, M. F. 1984. Contribution of small glaciers to global sea level. Science. 226:1418-1421.

Meier, M. F. 1990. Reduced rise in sea level. Nature 343:115.

Mercer, J. H. 1970. Antarctic ice and interglacial high sea levels. Science. 168:1605-1606.

Miller, T., J. C. Walker, G. T. Kingsley, and W. A. Hyman. 1989. Impact of global climate change on urban infrastructure. In Potential effects of global climate change on the United States: Appendix Infrastructure, ed. J. B. Smith and P. A. Tirpak, 2-2-2-37. Washington, DC: U. S. Environmental Protection Agency.

National Academy of Sciences. 1979. $\mathrm{CO}_{2}$ and climate: A scientific assessment. Washington, DC: National Academy of Sciences.

National Research Council. 1983. Probable future changes in sea level resulting from increased atmospheric carbon dioxide. In Changing climate. Washington, DC: National Academy Press.

National Research Council. 1987. Responding to changes in sea level: engineering implications. Washington, D.C.: National Academy Press.

Oldale, R. 1985. Late quaternary sea level history of New England: A review of published sea level data. Northeastern Geology. 7:192-200.

Peltier, W. R., and A. M. Tushingham. 1989. Global sea level rise and the greenhouse effect: Might they be connected?" Science. 244:806-810.

President's Science Advisory Committee. 1965. Restoring the quality of our environment. Washington, D.C.: President's Science Advisory Committee, The White House.

Smith, J. B., and D. A. Tirpak, eds. 1989. The potential effects of global climate change on the United States. Washington, DC: U.S. Environmental Protection Agency.

Sorensen, R. M., R. N. Weisman, and G. P. Lennon. 1984. Control of erosion, inundation, and salinity intrusion caused by sea level rise. See Barth and Titus, 1984.

Ramanathan, V., H. B. Singh, T. J. Cicerone, and J. T. Kiehl. 1985. Trace gas trends and their potential role in climate change. Journal of Geophysical Research 90(D3):5547-5566.

Revelle and Seuss. 1957. Carbon dioxide exchange between the atmosphere and ocean and the question of an increase of atmospheric $\mathrm{CO}_{2}$ during the past decade. Tellus. 9:18.

Titus, J. G. 1984. Planning for sea level rise before and after coastal disaster. In Greenhouse effect and sea level rise. See Barth and Titus . 1984.

Titus, J. G. ed.1985. Potential impacts of sea level rise on the beach at Ocean City, Maryland. Washington, DC: U.S. Environmental Protection Agency.

Titus, J. G. 1986. Greenhouse effect, sea level rise, and coastal zone management. Coastal Zone Management 14(3):147-171.

Titus, J. G. 1988. Greenhouse effect, sea level rise, and coastal wetlands. Washington, DC: U. S. Environmental Protection Agency.

Titus, J. G. 1990. Greenhouse effect, sea level rise, and barrier islands: Case study of Long Beach Island, New Jersey. Coastal Management. 18:65-90.

Titus, J. G. 1991. Greenhouse effect, sea level rise, and wetland policy: How Americans could abandon an area the size of Massachusetts at minimum cost. Environmental Management 15(1):39-58.

Titus, J. G., and M. S. Greene. 1989. An overview of studies estimating the nationwide cost of holding back the sea. In Potential Effects of Climate Change on the United States: Appendix B, Sea Level Rise, ed. J. B. Smith and D. A. Tirpak, 5-1-5-51. Washington, DC: U. S. Environmental Protection Agency.

Titus, J. G., C. Y. Kuo, M J. Gibbs, T. B. LaRoche, M. K. Webb, and J. O. Waddell. 1987. Greenhouse effect, sea level rise, and coastal drainage system. Journal of Water Resources Planning and Management 113:2.

Tyndall, J. 1863. On radiation through the earth's atmosphere. Philosophical Magazine. 4:200. U.S. Department of Energy. 1983. Proceedings to Carbon Dioxide Research Conference: Carbon Dioxide, Science, and Consensus. Conference 820970. Washington, D.C.: U. S. Department of Energy.

U.S. Environmental Protection Agency. 1983. Projecting future sea level rise. Washington, DC: U.S. Environmental Protection Agency.

U.S. Environmental Protection Agency and Louisiana Geological Survey. 1987. Saving Louisiana's coastal wetlands: The need for a long-term plan of action. Washington, D.C.: U.S. Environmental Protection Agency. 
Weggel, J. R., S. Brown, J. C. Escajadillo, P. Breen, and E. L. Doheny. 1989. The cost of defending developed shorelines along sheltered waters of the United States from a two-meter rise in mean sea level. In: Potential effects of global climate change on the United States: Appendix B, sea level rise. J. B. Smith and D. A. Tirpak, eds. Washington, DC: U.S. Environmental Protection Agency.

Wilcoxen, P. J. 1986. Coastal erosion and sea level rise: Implications for ocean beach and San Francisco's Westside Transport Project. Coastal Zone Management. 14(3):173-191.

Yohe, G. 1990. The cost of not holding back the sea: Toward a national sample of economic vulnerability. Coastal Management. 18:403-432. 